\title{
HIGH-YIELDING AND CHEMICALLY ENRICHED MAIZE HYBRIDS BRED IN SERBIA - THE BEST BASIS FOR SUPER QUALITY FEED AND FOOD
}

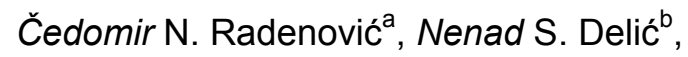
Milica M. Radosavljevićc, Života V. Jovanovićd, Mile D. Sečanski ${ }^{\mathrm{e}}$, Aleksandar S. Popovićf, Miloš S. Crevar ${ }^{g}$, Nebojša D. Radosavljević ${ }^{h}$

a Maize Research Institute „Zemun Polje“, Belgrade, Republic of Serbia; University of Belgrade, Faculty of Physical Chemistry, Belgrade, Republic of Serbia, e-mail: radenovic@sbb.rs, corresponding author, ORCID iD: (Dhttps://orcid.org/0000-0002-4997-7635

${ }^{\mathrm{b}}$ Maize Research Institute „Zemun Polje“, Belgrade, Republic of Serbia, e-mail: ndelic@mrizp.rs, ORCID iD: (i)https://orcid.org/0000-0003-4020-0114

"Maize Research Institute „Zemun Polje“, Belgrade, Republic of Serbia, e-mail: rmilica@mrizp.rs, ORCID iD: (i)https://orcid.org/0000-0002-1026-4582

${ }^{d}$ Maize Research Institute „Zemun Polje“, Belgrade, Republic of Serbia, e-mail: zjovanovic@mrizp.rs, ORCID iD: (Ohttps://orcid.org/0000-0002-4492-8797

e Maize Research Institute „Zemun Polje“, Belgrade, Republic of Serbia, e-mail: msecanski@mrizp.rs, ORCID iD: Dhttps://orcid.org/0000-0003-2070-4366

${ }^{f}$ Maize Research Institute „Zemun Polje“, Belgrade, Republic of Serbia, e-mail: dobropoljac@yahoo.com, ORCID iD: (1)https://orcid.org/0000-0002-4569-6799

${ }^{9}$ Maize Research Institute „Zemun Polje“, Belgrade, Republic of Serbia, e-mail: mcrevar@mrizp.rs, ORCID iD: (Dhttps://orcid.org/0000-0002-8828-4946

h Maize Research Institute „Zemun Polje“, Belgrade, Republic of Serbia, e-mail: 1965neboj@gmail.com, ORCID iD: (itttps://orcid.org/0000-0002-4131-3148

DOI: 10.5937/vojtehg69-29512; https://doi.org/10.5937/vojtehg69-29512

FIELD: Physical chemistry, Biophysics, Genetics, Biochemistry and Technologies for processing plant raw materials ARTICLE TYPE: Original scientific paper

ACKNOWLEDGMENT: These studies have been financially supported mainly by the Maize Research Institute "Zemun Polje“, Belgrade, and partly by the Ministry of Education, Science and Technological Development of the Republic of Serbia (Projects 03E211, 03E22, TR-20014, reference numbers 31028 and 31037). 


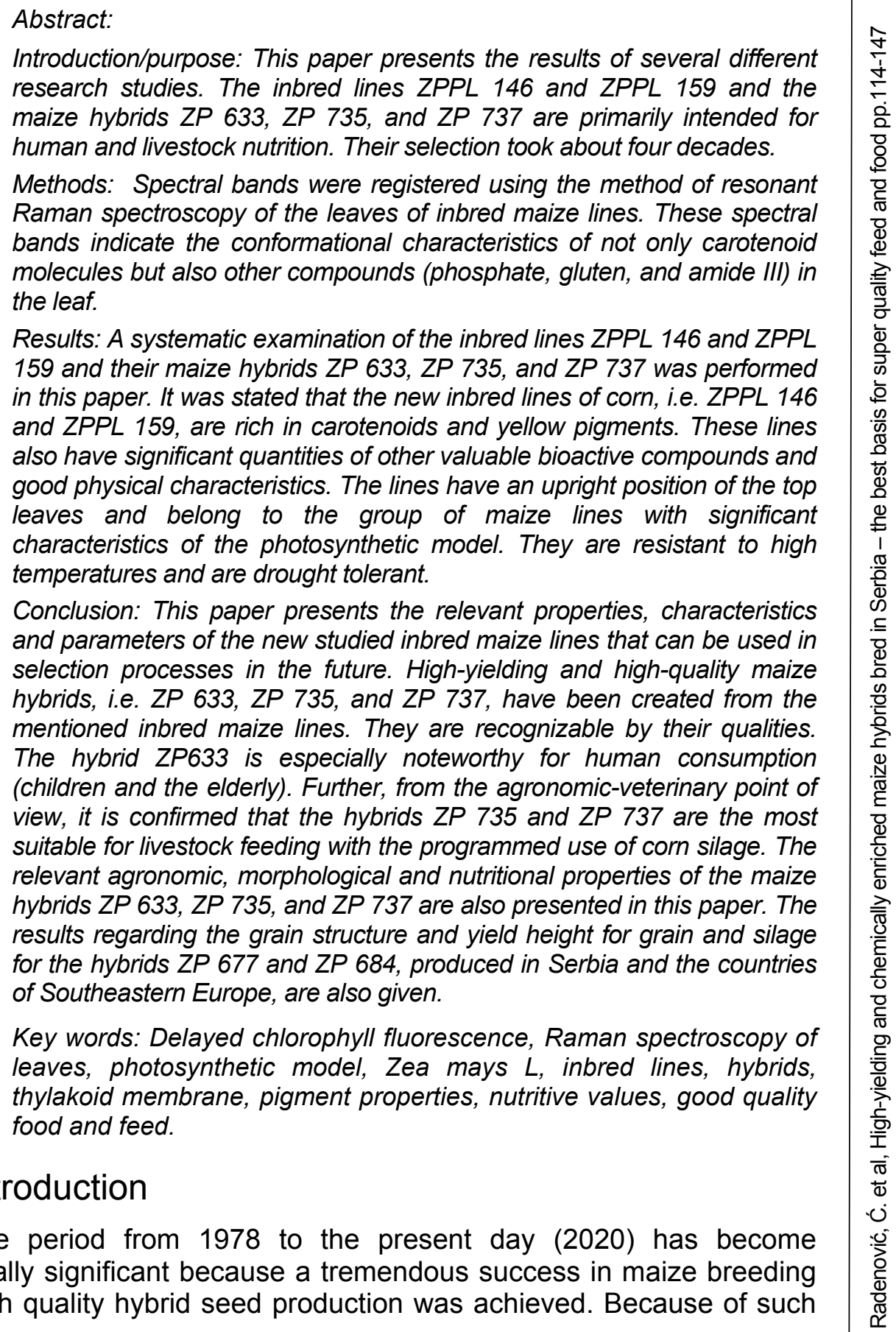


activities, over 1500 grain and silage hybrids have been derived (Duvick, 1984), (Sprague, 1984), (Trifunović, 1986), (Dumanović, 1986), (Hallauer, 1988) and (Ivanović et al, 1995).

Modern technical and technological prerequisites were provided for carrying out the process of breeding, efficient production of hybrid maize seeds and significant amounts of seeds of commercial and silage hybrids (Kojić \& Ivanović, 1986), (Petrović et al, 1992), (Pejić, 1994), (Jovanović, 1996, 1998), (Bekrić, 1997, 1999), (Dumanović \& Pajić, 1998), (Jovanović et al, 2000), (Radenović \& Somborac, 2000), (Antov et al, 2004), (Dinić \& Đorđević, 2005).

In the context of the stated dynamics of the development, interdependent studies of many scientific disciplines (physiology, biochemistry, biophysics, biotechnology, breeding, photosynthesis, Raman spectroscopy, infrared spectra of grain, processing technology of cereals, silage production practices, silage utilisation and food science) have been linked with the aim of modernising and efficient implementation of contemporary programmes on maize breeding and seed production (Radenović, 1994), (Pajić et al, 1995), (Radenović et al, 2004, 2008, 2009), (Radenović \& Somborac, 2000), (Konstantinov et al, 2010). In addition to the outstanding results achieved in the selection of standard grain and maize silage hybrids, there was a pressing need to develop new inbred lines and better quality maize hybrids with an improved chemical composition of the grain, especially in essential bioactive compounds. Moreover, the intensive work has been carried on the improvement and development of new methods for the preservation of plants, especially maize hybrid plants in the form of silage of the whole plant and grain. Silage is biologically fermented or chemically preserved feed of a plant origin. Silage maize growing practices differ, to a certain extent, from the practices used in the commercial maize cultivation. Namely, it is very important to produce the maximum quantity of silage per area unit and it is necessary that the produced silage be of high quality. Therefore, in order to succeed in this, it is necessary to select a plot with good soil properties, use high quality seed, apply the necessary amount of mineral fertilisers, perform proper and timely sowing and apply tested herbicides that have no residual effects and toxic effects on silage mass. All this has to provide silage that contains approximately $50 \%$ grain, as it is a prime quality part. Furthermore, it is important that the crop be disease free, so that there are no adverse effects in feeding ruminants and no negative effects on their health, quality of meat and milk, and dairy products. Nowadays, silage is the basis of cost-effective and contemporary animal husbandry and the closest substitute for green 
forage (Bekrić, 1997, 1999), (Dumanović \& Pajić, 1998), (Pejić, 1994), (Jovanović, 1996, 1998), (Jovanović et al, 2000), (Antov et al, 2004), (Dinić \& Đorđević, 2005), (Liu, 2007), (Strati et al, 2012), (Radenović, 2002, 2013), (Bacchetti et al, 2013), (Buxton \& Russel, 1988), (Đorđević \& Dinić, 2003), (Grubić et al, 1995), (Kurlich \& Juvik, 1999), (Lazarević et al, 1999), (Luo \& Wang, 2012), (Maksimović et al, 1971, 1997).

To meet many demands, justifiable and increased needs for functional and quality nutrition of people (mainly children and the elderly) and livestock (primarily cows and sheep), it was necessary to select new maize inbred lines with significantly richer pigment-complex properties and the exceptional nutritional value. This aim was achieved with the increased content of carotenoids and other bioactive compounds. With such inbred lines, it was possible to develop high-quality maize hybrids which would meet requirements of medicine, veterinary medicine and agronomy and be necessary for healthy food and feed, which was the objective of the present study.

\section{Materials and methods}

Plant material - The genetic and breeding studies of the new maize inbred lines have been performed for over 40 years. These inbreds, future parental forms, primarily ZPPL 146 and ZPPL 159, have increased chemical compositions, whereas the hybrids of high yields and extra quality derived from these inbreds are used as follows: ZP 633 standard in nutrition of children, the elderly and athletes; products: flour, semolina; ZP 737 - standard in nutrition of fattening chickens up to 1.5$3 \mathrm{~kg}$ and laying hens; products: ground maize, coarse meal, flour and grain silage; and ZP 735 - standards in nutrition of calves, fattening heifers, dairy cows, sheep, goats and pigs; products: coarse meal, ground maize, grain silage, ear silage and the whole plant silage. In recent times, the hybrids ZP 677 and ZP 684 have also been used for silage. Figure 1 shows the actual appearance of the elite maize inbred lines with erect top leaves, i.e. ZPPL 146, ZPPL 159, and high-quality maize hybrids ZP 633, ZP 735, and 737 with their erect top leaves.

The observed maize inbred lines and hybrids have the increased content of carotenoids and other bioactive compounds. They have been developed and owned by the Maize Research Institute, Zemun Polje, Belgrade, Serbia. 
A

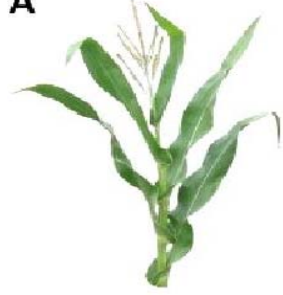

$\mathbf{C}$

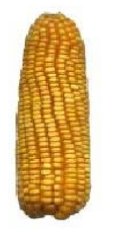

D

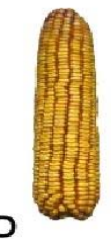

$\mathbf{B}$

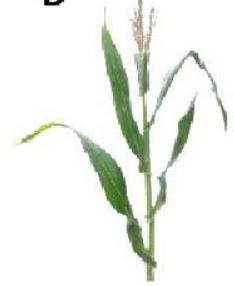

$\mathbf{E}$

Figure 1 - Actual appearance of the elite maize inbred lines with erect top leaves ZPPL $146(A)$ and ZPPL 159 (B) and the high-quality maize hybrids ZP 633 (C), ZP 735 (D) and $Z P 737$ (E) with their erect top leaves.

Puс. 1 - Внешний вид элитных инбредных линий кукурузы с прямостоячими верхними листьями ZPPL 146 (A), ZPPL 159 (B) и их высококачественных гибридов, ZP 633 (C), ZP 735 (D) и ZP 737 (E) с прямостоячими верхними листьями

Слика 1 - Стварни изглед елитних инбред-линија кукуруза са усправним положајем вриних листова: ZPPL 146 (A) и ZPPL 159 (B) и њихових висококвалитетних хибрида кукуруза: ZP 633 (C), ZP 735 (D) и ZP 737 (E) са усправним положајем вршних листова

Methods - Overall studies of the stated new inbred lines and hybrids with erect top leaves developed from these inbreds encompassed several series of experiments in which new and standard methods and procedures were applied.

1. Chemical compositions of the new inbred lines and high-quality maize hybrids

The methods applied to determine the grain chemical composition of the maize inbred lines and hybrids are generally accepted and standardised and already described in detail in previous papers (Radosavljević et al, 2000), (Bekrić, 1997), (White \& Jonson, 2003), (AACC, 2013), (Strati et al, 2012), (Radenović et al, 2010).

2. Resonance Raman spectroscopy method applied to the maize inbred lines

The measurements of resonance Raman spectroscopy of the maize inbred line leaves were done in accordance with the procedure and the 
method was described in our previously published papers (Radenović et al, 1994, 1998).

3. The measurement of the angle and the leaf area of the maize inbred lines

This series of experiments was related to studying the erect position of top leaves in the maize inbred lines. A specially designed protractor was used to measure the angle between the position of the above-ear leaf and the position of the plant stalk on the maize inbred lines. The leaf area was measured by the LI-3000 Portable Leaf Area Meter (LI-COR Biosciences, USA). The measurements of the angle between the aboveear leaf and the stalk and the leaf areas were carried out on 122 plants for each maize inbred line during the three-year period. These methodical procedures were described in the previously published papers (Radenović et al, 2009, 2010).

\section{Photosynthetic fluorescence measurements}

This series of the experiments was related to photosyntheticfluorescence studies, including thermal processes of delayed chlorophyll fluorescence, critical temperatures (phase transitions), and activation energies. The test maize inbreds were grown in the experimental field of the Maize Research Institute, Zemun Polje. The plants were brought from the experimental field to the laboratory between 7 a.m. and 8 a.m. These plants sampled in the field were transversally cut in the ground internode. In the laboratory, the plants were placed in water along the length of one internode. Prior to the fluorescence experiment, all plants were kept under the black ball glass for two hours. A segment of intact above ear leaves was taken from such plants and placed into a chamber of the phosphoroscope. The intact leaf segments were kept in the chamber (in the dark) for at least 15 minutes, and then the thermal processes of delayed chlorophyll fluorescence were measured. These tests were performed on 111 plants of each maize inbred line. An improved, noninvasive photosynthetic-fluorescence method was applied for these measurements. This method was developed at the Maize Research Institute and was described in the previously published papers (Radenović et al, 2002, 2004, 2007, 2008, 2010, 2013).

5. Survey of the breeding and seed production properties of the new maize inbred lines

Since these maize inbred lines with efficient photosynthesis, rich in pigments and with exceptional nutritive qualities are promising, a broad 
survey of their relevant breeding and seed production properties, traits and parameters obtained by standard methods of ranking (Radenović et al, 2007, 2008, 2009, 2013) are presented in this article.

6. Functional dependence of the yield of the studied maize grain and silage hybrids

Numerous and long-term studies on the yields (t ha-1) of the three high-yielding and high-quality grain and maize silage hybrids (ZP 633, ZP 735, ZP 737) were performed in many locations in Serbia and other countries of Southeastern Europe. Standard methods for maize production, tinning and processing were applied in these studies (Pejić, 1994), (Bekrić, 1997, 1999), (Jovanović, 1996, 1998), (Jovanović et al, 2000), (Antov et al, 2004), (Đorđević \& Dinić, 2003), (Dinić \& Đorđević, 2005), (Videnović et al, 2011), (Radenović, 2013).

7. Medical, veterinary, agronomic, and nutrition estimation of the need for human and animal nutrition with products based on maize hybrids bred for a specific purpose

7.1. Human nutrition with products based on maize hybrids enriched with pigments and other nutrition ingredients

Empirical efforts to acquire knowledge about the need for maize diet in human nutrition were initiated a long time ago, perhaps 300-400 years ago. Much later, in the 1950s, the scientific literature related to this topic emerged, primarily in medical institutions. However, the authors of this study became interested in this topic in the early 1990s (Radenović, 1991).

7.2. Animal nutrition with products based on maize hybrids bred for silage

It is believed that 1150 years have passed since the first procedures of preserving green crops (Goffart, 1877) and (Fry, 1885). Modern and improved technology of preserving crops by ensiling flourished as late as the early second half of the $20^{\text {th }}$ century (1955-1965) (Cross \& Jenny, 1976), (Bekrić, 1997, 1999), (Pejić, 1994), (Jovanović, 1998), (Jovanović et al, 2000), (Đorđević \& Dinić, 2003), (Dinić \& Đorđević, 2005). Modern, intensive and cost-effective production in cattle husbandry can no longer be imagined without silage. Furthermore, the advantages of such feed have been growing in goat and sheep breeding and to a lesser extent in pig breeding (Pejić, 1994), (Jovanović, 1996, 1998), (Jovanović et al, 2000), (Đorđević \& Dinić, 2003), (Dinić \& Đorđević, 2005), (Radenović, 2013). The authors of this paper became interested in this topic at the beginning of the $21^{\text {st }}$ century (in 2002). At that time, a great number of 
high-quality maize hybrids intended for production of high-quality silage were developed with the aim to regulate metabolic processes in domestic animals thus improving their growth and quality of meat and milk (Radenović, 2002).

\section{Results and discussion}

1. Chemical composition and physical traits of grain of maize inbred lines and high-quality maize hybrids

The results of the studies of the chemical composition and physical traits of the grains of the observed maize inbred lines and hybrids are presented in Table 1. The obtained results relate to important chemical and physical constituents.

Table 1 - Results obtained in the analyses of the chemical composition and physical traits of the grain of maize inbred lines and hybrids (Zea mays L.) (three-year average, trial field of the Maize Research Institute, Zemun Polje, Belgrade, Serbia)

Таблица 1 - Результаты анализа химического состава и фризических характеристик зерна элитных инбредных линий и гибридов кукурузы (Zea mays L.) (в среднем за 3 года, опытное поле Института кукурузы «Земун Поле», 2. Белград, Сербия)

Табела 1 - Резултати просечно трогодишњих анализа хемијског састава и фризичких карактеристика зрна инбред-линија и хибрида кукуруза (Zea mays L.) (огледно поље Института за кукуруз, Земун Поље, Београд, Србија)

\begin{tabular}{|c|c|c|c|c|c|c|c|}
\hline \multirow{3}{*}{$\begin{array}{l}\text { Chemical composition } \\
\text { and physical traits } \\
\text { of the maize (Zea mays L.) } \\
\text { grain }\end{array}$} & \multicolumn{2}{|c|}{ Published data* } & \multicolumn{5}{|c|}{$\begin{array}{l}\text { Average data of the observed grain for storage in } \\
\text { silos of the elite maize (Zea mays L.) inbred lines } \\
\text { and hybrids }\end{array}$} \\
\hline & \multirow{2}{*}{ Range } & \multirow{2}{*}{ Average } & \multicolumn{2}{|c|}{ Inbred lines } & \multicolumn{3}{|c|}{ Hybrids } \\
\hline & & & ZPPL 146 & ZPPL 159 & ZP 633 & ZP 735 & ZP 737 \\
\hline Moisture $\left(\%\right.$, wet basis $\left.{ }^{a}\right)$ & $7-23$ & 16.0 & 10.24 & 10.12 & 9.90 & 9.84 & 10.15 \\
\hline Starch (\%) & $61-78$ & 71.7 & 67.80 & 66.26 & 68.23 & 64.39 & 67.86 \\
\hline Protein (\%) & $6-12$ & 9.5 & 10.22 & 12.57 & 11.11 & 12.27 & 11.57 \\
\hline Fat (oil) (\%) & $1.0-5.7$ & 4.3 & 7.53 & 5.38 & 6.11 & 5.82 & 7.16 \\
\hline Ash (\%) & $1.1-3.9$ & 1.4 & 1.48 & 1.45 & 1.51 & 1.54 & 1.47 \\
\hline Cellulose (\%) & - & 3.0 & 2.26 & 2.33 & 2.37 & 2.43 & 2.00 \\
\hline Pentosans (as xylose), \% & $5.8-6.6$ & 6.2 & - & - & - & - & - \\
\hline Fibres, \% & 8.3-11.9 & 9.5 & - & - & - & - & - \\
\hline Cellulose + lignin, \% & 3.3-4.3 & 3.3 & - & - & - & - & - \\
\hline $\begin{array}{l}\text { Sugars, total (as glucose), } \\
\%\end{array}$ & $1.0-3.0$ & 2.6 & - & - & - & - & - \\
\hline $\begin{array}{l}\text { Yellow pigment, } \\
(\mu g \beta C E / g \text { d.m. })^{\star *}\end{array}$ & - & - & 19.00 & 18.10 & 27.30 & 21.90 & 21.60 \\
\hline Total carotenoids $(\mathrm{mg} / \mathrm{kg})$ & $12-36$ & 26.0 & 33.20 & 31.80 & 32.40 & 28.30 & 27.80 \\
\hline 1000-kernel weight $(\mathrm{g})$ & $217-438$ & 343.70 & 277.45 & 283.03 & 333.82 & 295.81 & 296.95 \\
\hline
\end{tabular}




\begin{tabular}{|c|c|c|c|c|c|c|c|}
\hline \multirow{3}{*}{$\begin{array}{l}\text { Chemical composition } \\
\text { and physical traits } \\
\text { of the maize (Zea mays L.) } \\
\text { grain }\end{array}$} & \multicolumn{2}{|c|}{ Published data* } & \multicolumn{5}{|c|}{$\begin{array}{l}\text { Average data of the observed grain for storage in } \\
\text { silos of the elite maize (Zea mays L.) inbred lines } \\
\text { and hybrids }\end{array}$} \\
\hline & \multirow{2}{*}{ Range } & \multirow{2}{*}{ Average } & \multicolumn{2}{|c|}{ Inbred lines } & \multicolumn{3}{|c|}{ Hybrids } \\
\hline & & & ZPPL 146 & ZPPL 159 & ZP 633 & ZP 735 & ZP 737 \\
\hline Test weight $\left(\mathrm{kg} / \mathrm{m}^{3}\right)$ & 693-843 & 791.00 & 829.84 & 844.96 & 809.03 & 808.27 & 817.07 \\
\hline Density $\left(\mathrm{g} / \mathrm{cm}^{3}\right)$ & $1.21-1.38$ & 1.26 & 1.27 & 1.29 & 1.27 & 1.28 & 1.28 \\
\hline Flotation index (\%) & $0-68$ & 27.10 & 10.56 & 10.68 & 25.12 & 13.36 & 7.91 \\
\hline Grinding resistance (\%) & $7.0-25.8$ & 15.90 & 8.77 & 14.33 & 15.80 & 13.27 & 11.07 \\
\hline $\begin{array}{l}\text { Hard endosperm fractions } \\
(\%)\end{array}$ & $54.3-71.3$ & 59.20 & 11.00 & 10.67 & 9.67 & 11.33 & 9.67 \\
\hline $\begin{array}{l}\text { Soft endosperm fractions } \\
(\%)\end{array}$ & $45.7-28,7$ & 40.80 & 23.33 & 18.66 & 23.33 & 21.67 & 23.33 \\
\hline Water absorption index & $\begin{array}{l}0.180- \\
0.284\end{array}$ & 0.245 & 0.245 & 0.237 & 0.215 & 0.237 & 0.227 \\
\hline
\end{tabular}

* Source: P.J. White \& L.A. Jonson (White \& Jonson,, 2003).

** Done by the AACC Methods 14-50.01 (AACC, 2013).

2. Conformational changes in carotenoid molecules in the leaf of mxe maize inbred lines

The Raman spectra are very suitable for studying photosynthetic pigments in terms of conformational changes of carotenoid molecules. The authors of the present study have been dealing with this topic for a long period of time (Radenović et al 1994, 1995, 1998).

However, this study will highlight some conformational changes in molecules of carotenoids in the leaf of the observed maize inbred lines. Thus, the following six characteristic resonance Raman spectral bands were established within the $900 \mathrm{~cm}^{-1}-1800 \mathrm{~cm}^{-1}$ interval of Raman frequencies: 962, 1026, 1160, 1187, 1206, and $1520 \mathrm{~cm}^{-1}$, Figure 2. 


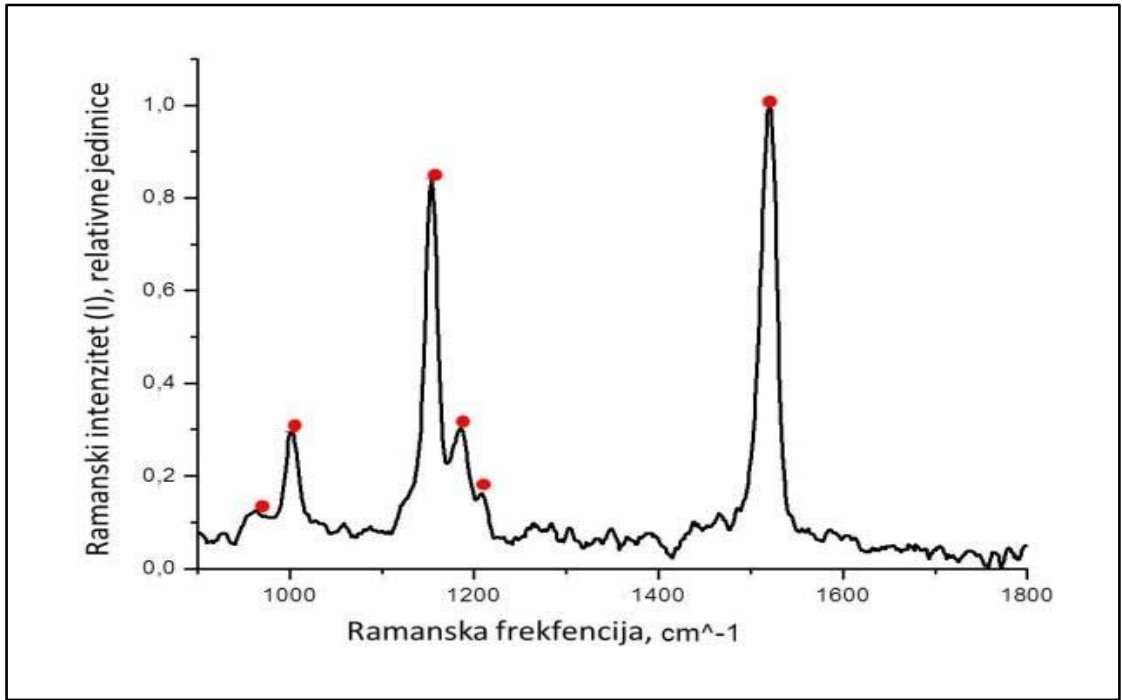

Figure 2 - Resonance Raman spectrum of the leaf of the maize inbred lines ZPPL 146 and ZPPL 159

Puс. 2 - Резонансная рамановская спектроскопия листа инбредной линии кукурузы ZPPL 146 и ZPPL 159.

Слика 2 - Резонантни Раманов спектар листа инбред-линија ZPPL 146 u ZPPL 159

Four spectral bands with lower intensities $\left(l_{926}, I_{1026}, I_{1187}, I_{1206}\right)$ were caused by conformational changes of phosphates, glycogens, and amides III. The remaining two spectral bands with significantly higher intensities $\left(I_{1160}, I_{1520}\right)$ have been regularly analysed in relation to the conformational changes in the carotenoid molecule. It is common to analyse the differences in the intensities of spectral bands $\left(I_{1520}\right.$ and $\left.I_{1160}\right)$ and even more often the differences in their ratio $\left(I_{1520} / I_{1160}\right)$. The resonance Raman spectrum of the leaf of the observed inbred lines with dominant spectral bands $\left(I_{1520}\right.$ and $\left.I_{1160}\right)$ is presented. This spectrum conditions the carotenoid molecules placed in the non-polar phase of the thylakoid membrane of the leaf of the inbred lines. In this paper, the effort was made to emphasize the application of resonance Raman spectroscopy in studying important vital functions of leaves of maize inbred lines, especially under agroecological conditions atypical for the maize growing region. Carotenoid molecules ( $\beta$ caroten, $\mathrm{C}_{40} \mathrm{H}_{56}$, with the activity of vitamin $A$, but also two xanthophylls: cryptoxanthin $\mathrm{C}_{40} \mathrm{H}_{56} \mathrm{O}$ and zeaxanthin $\mathrm{C}_{40} \mathrm{H}_{56} \mathrm{O}_{2}$ ), since localised in the non-polar phase of the 
thylakoid membrane of maize inbred leaves, showed to be a very suitable natural probe, capable of contributing to registering not only higher and more significant, but also smaller and finer conformational changes. These changes in the molecular structure of carotenoids may be expressed in the form of bending, stretching, compressing, and physical disruption of chemical bonds, which is caused by intensive actions of environmental factors, unfavourable critical temperatures in the first place. In the end, each conformational change in the carotenoid molecule unconditionally changes the function not only of the carotenoid molecule but also of the thylakoid membrane in leaves of maize inbred lines. Conformational changes in chemical bonds $-\mathrm{C}=\mathrm{C}-$ are reflected in the spectral band at $1520 \mathrm{~cm}^{-1}$. In addition, conformational changes in chemical bonds $=\mathrm{C}-\mathrm{C}=$ are reflected in the spectral band at $1160 \mathrm{~cm}^{-1}$ (Karnauhov, 1988).

3. The measure of the angle and the area of the above-ear leaf of maize inbred lines

The results of the measurements of the angles between the aboveear leaf and the stalk are presented in Table 2 as well as the average leaf areas. Based on the obtained angle measurement results, it can be stated that the observed maize inbred lines belong to the group of contemporary inbred lines with erect top leaves and the status of the photosynthetic model.

Table 2 - Angle between the above-ear leaf and the stalk and the leaf area of maize inbred lines with efficient photosynthesis

Таблица 2 - Угол наклона первого листа над початком и поверхности листьев новых инбредных линий кукурузы с эфрфективным фотосинтезом

Табела 2 - Величина угла првог листа изнад клипа и лисне површине нових инбред-линија кукуруза са ефикасном фотосинтезом

\begin{tabular}{|l|l|l|l|l|l|l|}
\hline \multirow{2}{*}{$\begin{array}{l}\text { Maize } \\
\text { inbred } \\
\text { line }\end{array}$} & $\begin{array}{l}\text { FAO } \\
\text { maturity } \\
\text { group }\end{array}$ & $\begin{array}{l}\text { Heterotic origin of the inbred } \\
\text { line }^{*}\end{array}$ & \multicolumn{2}{|l|}{$\begin{array}{l}\text { Angle of the } \\
\text { above-ear } \\
\text { leaf, }\left(^{\circ}\right)\end{array}$} & \multicolumn{2}{l|}{$\begin{array}{l}\text { Leaf area of the } \\
\text { above-ear leaf } \\
\left(\mathrm{cm}^{2}\right)\end{array}$} \\
\cline { 4 - 8 } & $\overline{\mathrm{X}}$ & $\sigma$ & $\overline{\mathrm{X}}$ & $\sigma$ \\
\hline $\begin{array}{l}\text { ZPPL } \\
146\end{array}$ & $650-700$ & $\begin{array}{l}\text { BSSS, USA } \\
\text { Zemun Polje }\end{array}$ & $20.8^{\circ}$ & 1.2 & 3762.7 & 238 \\
\hline $\begin{array}{l}\text { ZPPL } \\
159\end{array}$ & $550-600$ & $\begin{array}{l}\text { Landrace from Argentina } \\
\text { (S13) crossed to the in-bred } \\
\text { PE 25-10-1, Zemun Polje }\end{array}$ & $21.3^{\circ}$ & 1.2 & 2378.1 & 241 \\
\hline
\end{tabular}

*The observed maize inbred lines represent good heterotic pairs which have good combining abilities for grain yield and silage as well as good propagation and high yield. These inbreds are rich in pigments and have extraordinary nutritive qualities. 
4. Empirical procedure for photosynthetic and fluorescence studies on the above-ear leaf of maize inbred lines bred for the production of healthy food

The thermal processes of delayed chlorophyll fluorescence of the observed maize inbred lines intentionally selected for developing maize hybrids to be used in the production of various feed and food products were studied in detail.

The thermal curve is a curve that shows the changes in the delayed chlorophyll fluorescence level intensity depending on temperature. The trend of its establishment is most often analogous to changes in the duration in seconds for the segments designated with $a, b, c, d, e, f$, and $\mathrm{g}$, Figure 3, which was determined by the empirical procedure (Radenović et al, 2008, 2009, 2010).

Monitoring the course of the thermal curve and the analysis of the duration of certain segments provided data on the existence of a greater number of critical temperatures (phase transition temperatures) at which greater or smaller structural and functional changes occurred in the thylakoid membrane of the observed maize inbred lines.

In accordance with such information, it is possible to draw a conclusion on their different responses to the phenomena of resistance, drought and high temperature as well as on the phenomenon of their adaptation.

5. The exact temperature dependence of the delayed chlorophyll fluorescence intensity for the thylakoid membrane of new maize inbred lines bred for the production of healthy food

The changes in the intensity of the stationary level of delayed chlorophyll fluorescence $\left(\mathrm{I}_{\mathrm{DF}}\right)$ depending on temperature which ranges from $25^{\circ} \mathrm{C}$ to $60^{\circ} \mathrm{C}$ were measured. The dynamics of the changes of the temperature dependence for the observed maize inbred lines is presented in Figures 4a and 4b. 


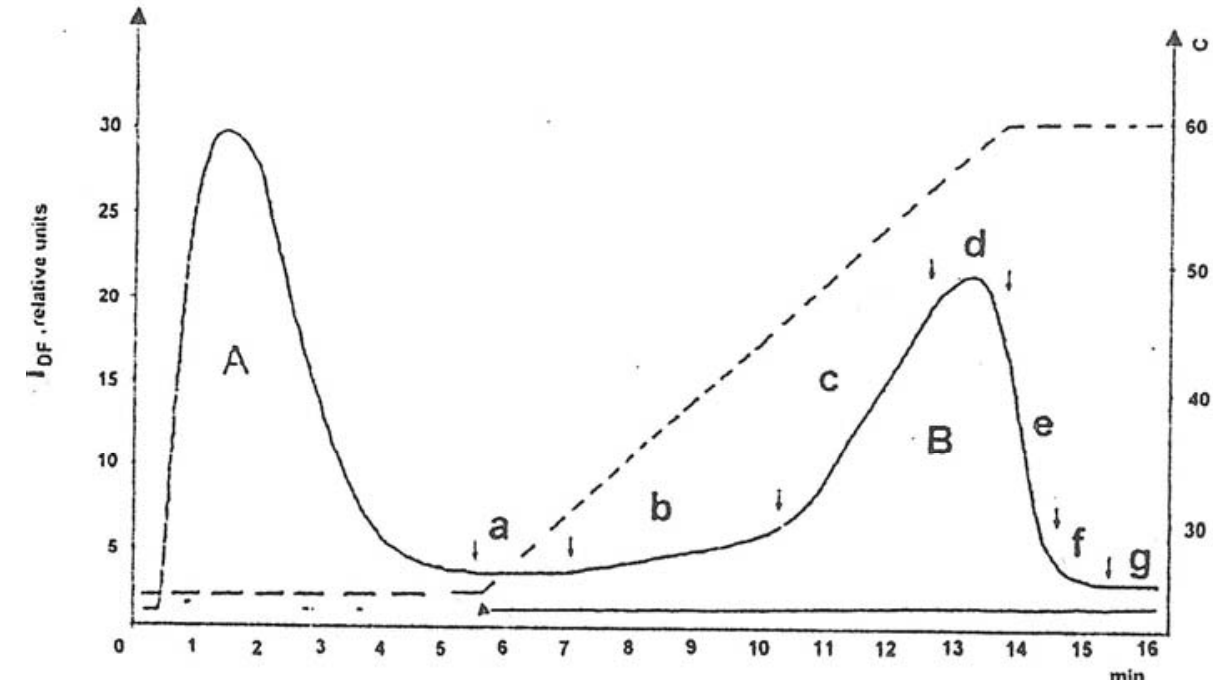

Figure 3 - Schematic presentation of the empirical procedure of typical changes of delayed chlorophyll fluorescence intensities $\left(I_{D F}\right)$ on the intact above-ear leaf of the observed maize inbred lines with significant breeding properties (solid line) and changes of temperatures (dashed line): the curve $A$ indicates induction processes of delayed chlorophyll fluorescence, while the curve $B$ encompasses photosynthetic fluorescence thermal processes of delayed chlorophyll fluorescence. Typical temporal segments ( $a, b$, $c, d, e, f$, and $g$ ) on the thermal curve $B$ correspond to the dynamics of $I_{D F}$ changes at the time of delayed chlorophyll fluorescence formation. Conformational and functional changes in the thylakoid membrane of the observed maize inbred lines with erect top leaves occur at the interception points of typical temporal segments.

Pис. 3 - Схематическое изображение типичных изменений интенсивности замедленной фрлуоресценции хлорофилла на интактных листьях наблюдаемых инбредных линий кукурузы (сплошная линия) и изменениями температуры (пунктирная линия): кривая А обозначает индукционные процессы замедленной фрлуоресценции хлорофилла, а кривая $B$ - тепловые процессы замедленной фрлуоресценции хлорофилла. Типичные временные сегменты (a, b, c, d, e, fu g) на тепловой кривой B соответствуют динамике изменений $I_{D F}$ во время образования замедленной фллуоресценции хлорофилла. Конформационные и функциональные изменения тилакоидной мембраны наблюдаемых инбредных линий кукурузы с прямостоячими верхними листьями происходят в точках пересечения типичных временных сегментов.

Слика 3 - Схематски приказ типичних промена интензитета закаснеле фолуоресценције хлорофила на интактном листу проучаваних инбред-линија кукуруза (пуна линија) и промене температуре (испрекидана линија): крива $A$ означава индукционе процесе дела криве закаснеле фрлуоросценције хлорофрила, а крива В обухвата термалне процесе дела криве закаснеле фрлуоресценције хлорофила. Типични временски сегменти $(a, b, c, d, e, f, u g)$ на термалној кривој $B$ одговарају динамици промена $I_{D F}$ за време формирања закаснеле фрлуоросценције хлорофила. До конфрормационих и фрункционалних промена у тилакоидној мембрани проучаваних инбред-линија кукуруза са усправним положајем вршних листова долази у тачкама интерцепције типичних временских сегмената. 


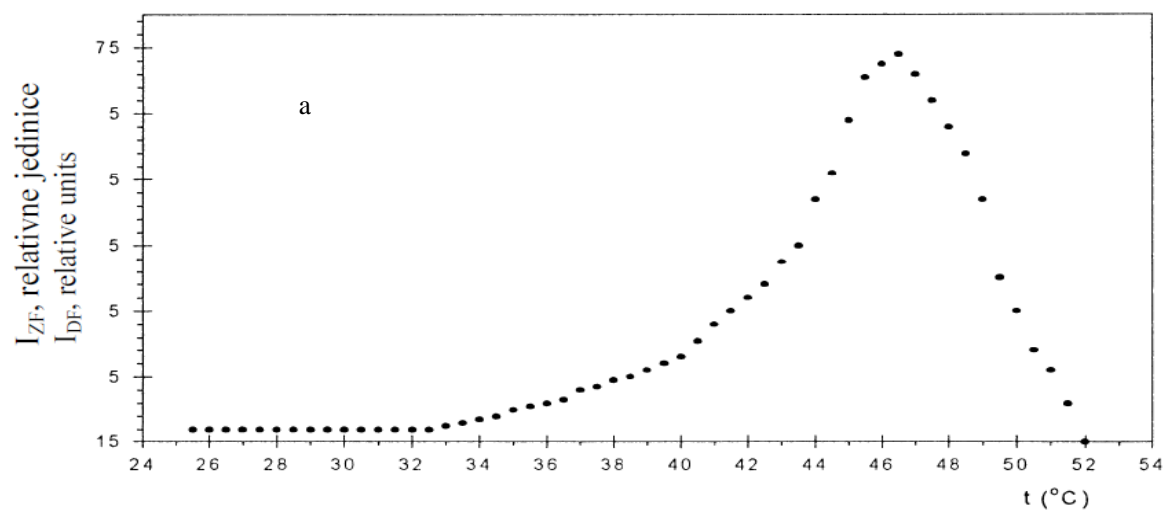

Figure 4 - Changes in the intensity of the delayed chlorophyll fluorescence $\left(I_{D F}\right)$ of the thermal processes depending on temperature in the thylakoid membrane and chloroplasts of the intact above-ear leaf of the new air dried maize inbred lines ZPPL 146 (a) and ZPPL 159 (b).

Puc. 4 - Изменение интенсивности замедленной фрлуоресценции хлорофрилла (IDF) тепловых процессов в зависимости от температуры в тилакоидной мембране и хлоропластах интактного первого листа над новыми початками инбредных линий кукурузы ZPPL 146 (а) и ZPPL 159 (б), обработанных воздушной сушкой

Слика 4 - Промене интензитета закаснеле фрлуоресценције хлоросрила (IDF) термалних процеса у зависности од температуре у тилакоидној мембрани и хлоропластима интактног првог листа изнад клипа нових инбред-линија кукуруза ZPPL 146 (a) и ZPPL 159 (b) третираних ваздушним сушењем 
5.1. The Arrhenius plot for the determination of critical temperatures and conformational changes in chloroplasts and thylakoid membranes of the new maize inbred lines bred for the production of healthy food

The Arrhenius plot is based on the linearisation of the delayed chlorophyll fluorescence exact temperature dependence of the observed maize inbreds. Critical temperatures (phase transition temperatures) at which conformational changes occur in chloroplasts and the thylakoid membrane are determined by the application of the Arrhenius plot. Figures $5 \mathrm{a}$ and $5 \mathrm{~b}$ present the results of the Arrhenius plot application to the observed maize inbred lines.

Such dependence (Figures $5 a$ and $5 b$ ) is known as the Arrhenius plot for the determination of critical temperatures that cause conformational and functional changes, of chemical nature, in chloroplasts and the thylakoid membrane. Using the Arrhenius plot and linearisation of the exact temperature dependence of DF chlorophyll, all critical temperatures (phase transition temperatures) at which even the smallest conformational change occurred in the thylakoid membrane of the new air dried maize inbred lines were determined.

The values of critical temperatures in ${ }^{\circ} \mathrm{C}$, their frequency and interdistance characterise the observed new inbred lines with erect top leaves in relation to their tolerance, resistance and adaptability to increased and high temperatures as well as to drought (Radenović et al, 2013). The Arrhenius plot is based on the existence of straight lines. Each Arrhenius's straight line represents activation energy (Ea). The intercept of two straight lines is denoted by the critical temperature.

The results of Ea values in the ascending and descending parts of the thermal curve are explained by the fact that with the temperature increase, smaller or larger conformational and functional changes occur in pigment molecules (chlorophyll, carotenoids) in the thylakoid membrane and chloroplasts. Due to the changes, these molecules became more reactive thus acquiring additional energy which was used in the recombination process of DF chlorophyll formation (Radenović et al, 2013). 


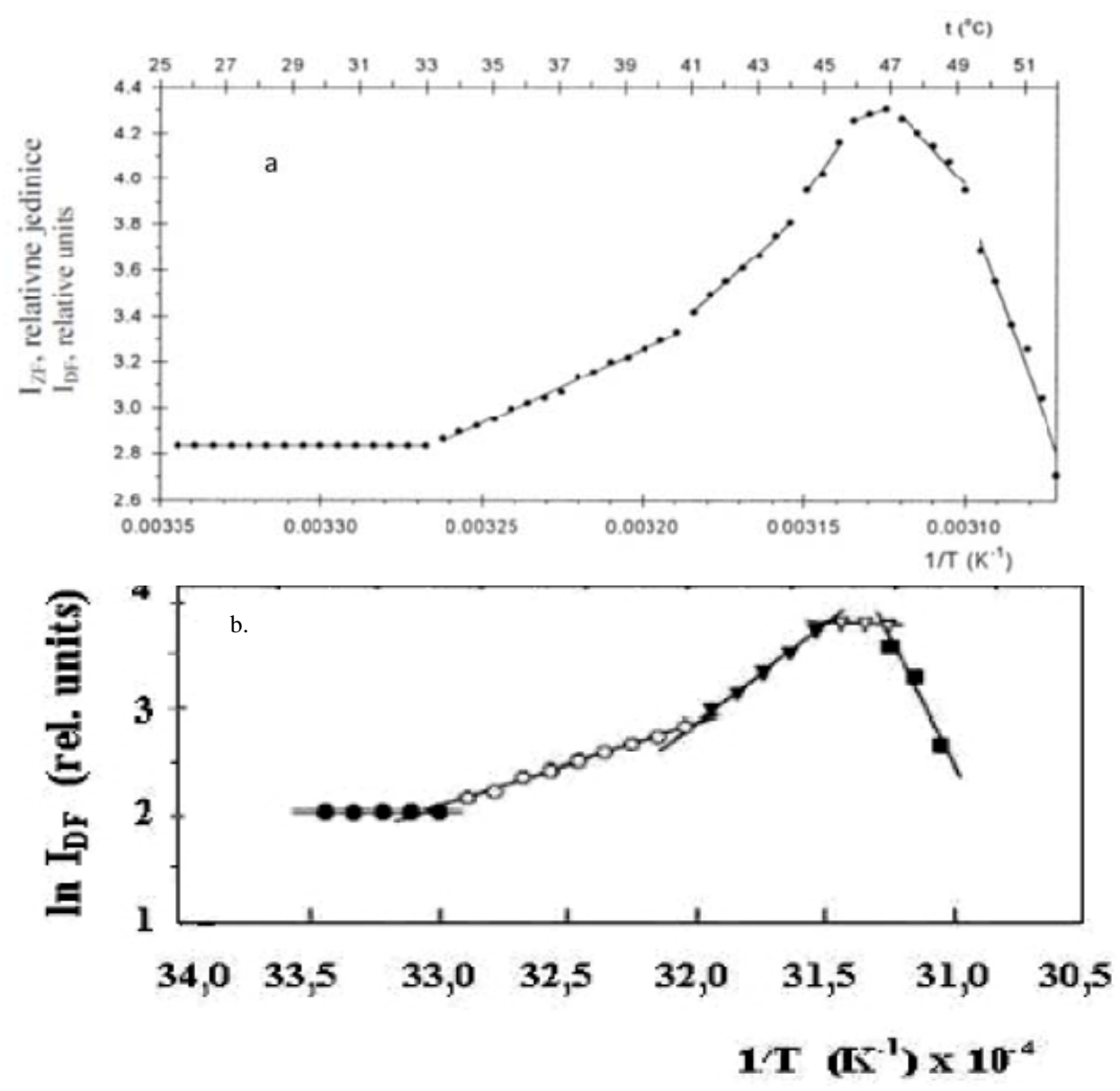

Figure 5 - The change of the logarithm of the delayed chlorophyll fluorescence intensity (In $\left.I_{D F}\right)$ of the thermal processes as a function of the reciprocal temperature value in the thylakoid membrane and chloroplasts of the intact above-ear leaf of the observed air dried maize inbred lines ZPPL 146 (a) and ZPPL 159 (b).

Pис. 5 - Изменение логарифрма интенсивности замедленной фрлуоресценции хлорофилла ( $\left.\mathrm{L}_{\mathrm{n}} \mathrm{I}_{\mathrm{zf}}\right)$ тепловых процессов в зависимости от обратного значения температуры в тилакоидной мембране и хлоропластах интактного первого листа над початками наблюдаемых инбредных линий кукурузы ZPPL 146 (a) и ZPPL 159 (б), обработанных воздушной сушкой

Слика 5 - Промене логаритма интензитета закаснеле фрлуоресценције хлорофрила ( $\left.L_{n} I_{z f}\right)$ термалних процеса у зависности од реципрочне вредности температуре у тилакоидној мембрани и хлоропластима интактног првог листа изнад клипа проучаваних инбред-линија кукуруза ZPPL 146 (a) и ZPPL 159 (b) које су третиране ваздушним сушењем 

healthy food

Detailed studies of the thermal processes of delayed chlorophyll fluorescence, and especially the analysis of the experimental thermal curve, encompassed not only the temperature dependence and the Arrhenius plot, but also the estimation of the values of activation energies (Ea) for the critical temperatures (phase transition temperatures) in chloroplasts and the thylakoid membranes of the observed maize inbreds bred for the production of healthy food, i.e. ZPPL 146 (a) and ZPPL 159 (b). The obtained results are shown in Table 3.

Table 3 - Changes in activation energies (Ea) and critical temperatures $\left(t^{\circ} \mathrm{C}\right)$ during the thermal processes in chloroplasts and the thylakoid membrane of the intact above-ear leaf of air dried maize inbred lines

Таблица 3 - Изменение энергий активации ( $\left.E_{a}\right)$ и критических температур $\left(t^{\circ} C\right)$ при тепловых процессах в хлоропластах и тилакоидной мембране интактного листа над початком инбредных линий, обработанных воздушной сушкой Табела 3 - Промена енергија активације $\left(E_{a}\right)$ и критичних температура $\left(t^{\circ} \mathrm{C}\right)$ за време термалних процеса у хлоропластима и тилакоидној мембрани интактног првог листа изнад клипа инбред-линија кукуруза третираног ваздушним сушењем

\begin{tabular}{|l|l|l|l|}
\hline ZPPL 146 & \multicolumn{2}{l|}{ ZPPL 159 } \\
\hline $\mathrm{Ea}, \mathrm{kJ} / \mathrm{mol}$ & $\mathrm{t}^{\circ} \mathrm{C}$ & Ea, kJ/mol & $\mathrm{t}{ }^{\circ} \mathrm{C}$ \\
\hline$I$ & 33.5 & $/$ & 25 \\
\hline 54.5 & 40.0 & 32.0 & 30 \\
\hline 105.0 & 44.0 & 100.3 & 38 \\
\hline 174.0 & 46.0 & 176.7 & 42 \\
\hline 41.0 & 47.0 & 259.9 & 47 \\
\hline 128.5 & 49.0 & $/$ & 50 \\
\hline \hline 326.0 & $/$ & & \\
\hline
\end{tabular}

6. Brief survey of the breeding and seed production traits of the new maize inbred lines with efficient photosynthesis

The observed new maize inbred lines ZPPL 146 and ZPPL 159 are very promising in the process of maize breeding. For these reasons, some relevant observations of their selected traits, performances, and parameters are presented in Table 4. 
Table 4 - Relevant breeding and seed production traits of the new maize inbred lines with photosynthetic efficiency

Таблица 4 - Релевантные селекционные и семеноводческие признаки новых инбредных линий кукурузы с эфрорективным фоотосинтезом

Табела 4 - Релевантна селекциона и семенарска својства нових инбред-линија кукуруза са ефикасном фотосинтезом

\begin{tabular}{|c|c|c|c|}
\hline \multirow{2}{*}{$\begin{array}{l}\text { Ordinal } \\
\text { numeral }\end{array}$} & \multirow[t]{2}{*}{ Name and definition of a trait } & \multicolumn{2}{|c|}{$\begin{array}{l}\text { Brief description of the breeding and seed } \\
\text { production traits of the maize inbred lines }\end{array}$} \\
\hline & & ZPPL 146 & ZPPL 159 \\
\hline 1. & Heterotic origin & $\begin{array}{l}\text { BSSS, USA, Zemun } \\
\text { Polje }\end{array}$ & $\begin{array}{l}\text { Landrace from } \\
\text { Argentina (S13), } \\
\text { crossed to the } \\
\text { inbred PE 25-10-1, } \\
\text { Zemun Polje }\end{array}$ \\
\hline 2. & FAO maturity group & $650-700$ & $550-600$ \\
\hline 3. & $\begin{array}{l}\text { Grain yield } \mathrm{ha}^{-1} \text { in } \mathrm{kg} \text { at } 14 \% \\
\text { moisture } \\
\text { a) dry land farming } \\
\text { b) irrigation }\end{array}$ & $\begin{array}{l}3500 \\
5000\end{array}$ & $\begin{array}{l}2000 \\
3000\end{array}$ \\
\hline 4. & $\begin{array}{l}\text { Number of plants ha }{ }^{-1} \text { at } \\
\text { harvest } \\
\text { a) dry land farming } \\
\text { b) irrigation }\end{array}$ & $\begin{array}{l}50000 \\
60000\end{array}$ & $\begin{array}{l}50000 \\
60000\end{array}$ \\
\hline 5. & Stalk properties & $\begin{array}{l}\text { Stalk is moderately } \\
\text { high with a prolific } \\
\text { trait. Tassel has an } \\
\text { elongated central } \\
\text { branch with fewer } \\
\text { side branches }\end{array}$ & $\begin{array}{l}\text { Stalk is short. Tassel } \\
\text { has closed side } \\
\text { branches that shed } \\
\text { for a long time }\end{array}$ \\
\hline 6. & Stalk resistance to lodging & $\begin{array}{l}\text { Inbred is resistant to } \\
\text { lodging }\end{array}$ & $\begin{array}{l}\text { Inbred is resistant to } \\
\text { lodging }\end{array}$ \\
\hline 7. & $\begin{array}{l}\text { Erect position of above ear } \\
\text { leaves }\end{array}$ & $\begin{array}{l}\text { first leaf }<20.8^{\circ} \\
\text { second leaf }<17.9^{\circ} \\
\text { third leaf }<15.3^{\circ}\end{array}$ & $\begin{array}{l}\text { first leaf }<21.3^{\circ} \\
\text { second leaf }<18.1^{\circ} \\
\text { third leaf }<15.4^{\circ}\end{array}$ \\
\hline
\end{tabular}




\begin{tabular}{|c|c|c|c|}
\hline \multirow{2}{*}{$\begin{array}{l}\text { Ordinal } \\
\text { numeral }\end{array}$} & \multirow[t]{2}{*}{ Name and definition of a trait } & \multicolumn{2}{|c|}{$\begin{array}{l}\text { Brief description of the breeding and seed } \\
\text { production traits of the maize inbred lines }\end{array}$} \\
\hline & & ZPPL 146 & ZPPL 159 \\
\hline 8. & Stay green & $\begin{array}{l}\text { Leaf remained } \\
\text { green until harvest }\end{array}$ & $\begin{array}{l}\text { Leaf remained } \\
\text { moderately green } \\
\text { until harvest }\end{array}$ \\
\hline 9. & $\begin{array}{l}\text { Tolerance of the inbred to } \\
\text { stress factors (drought and } \\
\text { high temperatures, etc.) }\end{array}$ & $\begin{array}{l}\text { Inbred is tolerant to } \\
\text { drought and high } \\
\text { temperatures }\end{array}$ & $\begin{array}{l}\text { Inbred is tolerant to } \\
\text { drought and high } \\
\text { temperatures }\end{array}$ \\
\hline 10. & Kernel traits and cob colour & $\begin{array}{l}\text { Semi-dent type, } \\
\text { orange kernels, } \\
\text { white cob }\end{array}$ & $\begin{array}{l}\text { Semi-flint, orange } \\
\text { kernels, red cob }\end{array}$ \\
\hline 11. & $\%$ grain moisture at harvest & $20-25$ & $20-25$ \\
\hline 12. & $\begin{array}{l}\text { Dry down rate in the stage of } \\
\text { grain maturing }\end{array}$ & $\begin{array}{l}\text { Dry down rate is not } \\
\text { fast, but hybrids are } \\
\text { suited for silage }\end{array}$ & $\begin{array}{l}\text { Dry down rate is not } \\
\text { fast, but hybrids are } \\
\text { suited for silage }\end{array}$ \\
\hline 13. & Harvest of inbreds & Harvest is easy & Harvest is easy \\
\hline 14. & Emergence of inbreds & Inbred emerges well & Inbred emerges well \\
\hline 15. & Early growth of inbreds & $\begin{array}{l}\text { Early growth is } \\
\text { moderate }\end{array}$ & $\begin{array}{l}\text { Early growth is } \\
\text { moderate }\end{array}$ \\
\hline 16. & $\begin{array}{l}\text { Suitability of the hybrid grain } \\
\text { for nutrition of ruminants and } \\
\text { nonruminants }\end{array}$ & $\begin{array}{l}\text { Grain of the hybrid } \\
\text { developed from this } \\
\text { inbred is suitable for } \\
\text { nutrition of } \\
\text { ruminants, } \\
\text { nonruminants, } \\
\text { human nutrition and } \\
\text { for industrial } \\
\text { processing }\end{array}$ & $\begin{array}{l}\text { Grain of the hybrid } \\
\text { developed from this } \\
\text { inbred is suitable for } \\
\text { nutrition of } \\
\text { ruminants, } \\
\text { nonruminants, } \\
\text { human nutrition and } \\
\text { for industrial } \\
\text { processing }\end{array}$ \\
\hline 17. & $\begin{array}{l}\text { Carotene content in the inbred } \\
\text { grain }\end{array}$ & $33.2(\mathrm{mg} / \mathrm{kg})$ & a) $31.8(\mathrm{mg} / \mathrm{kg})$ \\
\hline 18. & $\begin{array}{l}\text { Suitability of the inbred for the } \\
\text { development of silage hybrids }\end{array}$ & $\begin{array}{l}\text { Inbred is very } \\
\text { suitable for } \\
\text { developing silage } \\
\text { hybrids }\end{array}$ & $\begin{array}{l}\text { Inbred is very } \\
\text { suitable for } \\
\text { developing silage } \\
\text { hybrids }\end{array}$ \\
\hline 19. & Digestibility of hybrids & $\begin{array}{l}\text { Hybrids developed } \\
\text { from this inbred } \\
\text { have good } \\
\text { digestibility of the } \\
\text { whole plant and of } \\
\text { the grain }\end{array}$ & $\begin{array}{l}\text { Hybrids developed } \\
\text { from this inbred } \\
\text { have good } \\
\text { digestibility of the } \\
\text { whole plant and of } \\
\text { the grain }\end{array}$ \\
\hline
\end{tabular}




\section{Functional dependence of the yield of the observed grain and}

maize silage hybrids

The high-yielding and high-quality maize hybrids ZP 735, ZP 737, ZP 677, and ZP 684 are mainly intended for grain and silage production of grain, ear and the whole plant, under the agroecological conditions of Southeastern Europe. According to our studies and good agricultural practice, the hybrid ZP 633 is very suitable for human diet (Radenović, 1991). However, the hybrids ZP 735, ZP 737, ZP 677, and ZP 684 are significantly better for nutrition of domestic animals through high-quality grain silage and even more often the whole plant silage. The important agronomic and morphological traits of these hybrids are presented in Tables 5 - 9.

Table 5 - Agronomic traits of the observed maize hybrids

Таблица 5 - Агрономические характеристики испытуемых гибридов кукурузы Табела 5 - Агрономске карактеристике испитиваних хибрида кукуруза

\begin{tabular}{|c|c|c|c|}
\hline \multirow{2}{*}{ Agronomic traits } & \multicolumn{3}{|l|}{ Hybrid } \\
\hline & ZP 633 & ZP 735 & ZP 737 \\
\hline Hybrid type & SC & SC & SC \\
\hline FAO maturity group & $550-650$ & $750-850$ & $750-850$ \\
\hline Plant height $(\mathrm{cm})$ & 250 & 280 & 290 \\
\hline Ear height $(\mathrm{cm})$ & 120 & 130 & 135 \\
\hline 1000-kernel weight (g) & 380 & 370 & 370 \\
\hline Kernel type & semi-dent & dent & dent \\
\hline $\begin{array}{l}\text { Sowing density of silage } \\
\text { hybrid }\left(x 10^{3} \text { plants ha }{ }^{-1}\right)\end{array}$ & $60-70$ & $70-75$ & $70-75$ \\
\hline Leaf position on the plant & semi-erect to erect & $\begin{array}{l}\text { semi-erect to } \\
\text { erect }\end{array}$ & $\begin{array}{l}\text { semi-erect to } \\
\text { erect }\end{array}$ \\
\hline Tolerance to drought & good & good & good \\
\hline Tolerance to diseases & good & good & good \\
\hline Leaf appearance at harvest & stay green & stay green & stay green \\
\hline $\begin{array}{l}\text { Hybrid growing regions } \\
\text { (altitude, } \mathrm{m} \text { ) }\end{array}$ & $300-400$ & $250-400$ & $250-400$ \\
\hline Hybrid biomass yield $\left(\mathrm{t} \mathrm{ha}^{-1}\right)$ & $60-65$ & $75-80$ & $75-80$ \\
\hline Hybrid grain yield $\left(\mathrm{t} \mathrm{ha}^{-1}\right)$ & $7.819^{*}$ & $8.108^{* *}$ & $12.732^{\star *}$ \\
\hline
\end{tabular}

${ }_{* *}^{*}$ Hybrid yield achieved in 30 locations in Serbia in the 2008-2011 period ${ }^{* *}$ Hybrid yield achieved in 6 locations in Greece in the 2006-2009 period 
Table 6 - Ear morphological traits of the observed maize hybrids with a grain structure

Таблица 6 - Морфологические характеристики испытуемых початка и структуры строения зерна гибридов кукурузы

Табела 6 - Морфолошке карактеристике клипа испитиваних хибрида кукуруза са структуром зрна

\begin{tabular}{|l|l|l|l|}
\hline \multirow{2}{*}{ Traits } & \multicolumn{3}{|l|}{ Hybrid } \\
\cline { 2 - 4 } & ZP 633 & ZP 735 & ZP 737 \\
\hline Grain moisture (\%) & 18 & 19 & 20 \\
\hline Ear length (cm) & 22 & 25 & 25 \\
\hline Ear weight (g) & 252.3 & 286.4 & 226.7 \\
\hline Rows per ear & 16 & 18 & 18 \\
\hline Kernel row number & 700 & 800 & 850 \\
\hline Kernel weight on ear (g) & 228.4 & 248.4 & 200.4 \\
\hline \% kernel pericarp on ear & 5.3 & 6.5 & 4.6 \\
\hline$\%$ kernel embryo on ear & 11.3 & 12.1 & 10.7 \\
\hline \% kernel endosperm on ear & 83.4 & 81.4 & 84.7 \\
\hline
\end{tabular}

Table 7 - Whole plant silage yield depending on the maize hybrid sowing density Таблица 7 - Выход цельнозернового силоса в зависимости от плотности посева гибрида кукурузы

Табела 7 - Приноси силаже целе биљке у зависности од густине усева испитиваних хибрида кукуруза

\begin{tabular}{|c|c|c|c|c|c|}
\hline \multirow[b]{3}{*}{ Hybrid } & \multicolumn{4}{|c|}{ Sowing density $(000 / \mathrm{ha})$} & \multirow{3}{*}{$\begin{array}{l}\text { Grain } \\
\text { moisture in } \\
\text { silage period } \\
(\%)\end{array}$} \\
\hline & 55 & 60 & 65 & 70 & \\
\hline & $\begin{array}{l}\text { Whole } \\
\text { plant silage } \\
\text { yield (t/ha) }\end{array}$ & $\begin{array}{l}\text { Whole } \\
\text { plant silage } \\
\text { yield (t/ha) }\end{array}$ & $\begin{array}{l}\text { Whole plant } \\
\text { silage yield } \\
(\mathrm{t} / \mathrm{ha})\end{array}$ & $\begin{array}{l}\text { Whole } \\
\text { plant silage } \\
\text { yield (t/ha) }\end{array}$ & \\
\hline ZP 677 & 66.60 & 71.80 & 76.20 & 78.60 & 28.5 \\
\hline ZP 684 & 56.10 & 61.80 & 66.09 & 72.40 & 29.3 \\
\hline ZP 735 & 62.42 & 67.62 & 72.82 & 77.28 & 31.4 \\
\hline ZP 737 & 64.50 & 69.50 & 74.70 & 78.90 & 32.1 \\
\hline
\end{tabular}

The results of the silage yields of the whole plant as a function of the sowing density of the observed maize hybrids (Table 7 ) should be taken conditionally. They indicate a possible trend of silage yield increase of the whole plant depending on the crop densities. It should be noted that the silage yield of the whole plant depended, to a large extent, on the type of soil, supply of nutrients, crop protection products, water and other measures within contemporary crop growing practices (Jovanović, 1996, 1998), 
(Jovanović et al, 2000), (Antob et al, 2004), (Dinić \& Đorđević, 2005), (Radenović, 2013), (Đorđević \& Dinić, 2003).

Table 8 - Yield of fresh matter, dry matter and digestible dry matter of the observed maize hybrids sown at the common sowing density under arid conditions

Таблица 8-Выход зеленой массы, сухого и легкоусвыояемого вещества из испытуемых гибридов кукурузы, засеянных при обычной густоте посева в условиях засухи

Табела 8 - Принос зелене масе биљака, суве материје и сварљиве суве материје за проучаване хибриде кукуруза на уобичајеној густини биљака у аридним условима

\begin{tabular}{|l|l|l|l|l|l|}
\hline \multirow{2}{*}{ Hybrid } & \multirow{2}{*}{$\begin{array}{l}\text { Fresh } \\
\text { matter yield } \\
\left(\mathrm{t} \cdot \mathrm{ha}^{-1}\right)\end{array}$} & $\begin{array}{l}\text { Dry matter yield } \\
\text { Whole plant } \\
\text { yield } \\
\left(\mathrm{t} \cdot \mathrm{ha}^{-1}\right)\end{array}$ & $\begin{array}{l}\text { Plant } \\
\text { without ear } \\
\text { yield } \\
\left(\mathrm{t} \cdot \mathrm{ha}^{-1}\right)\end{array}$ & $\begin{array}{l}\text { Ear } \\
\text { yield } \\
\left(\mathrm{t} \cdot \mathrm{ha}^{-1}\right)\end{array}$ & $\begin{array}{l}\text { Digestible dry } \\
\text { matter yield } \\
\left(\mathrm{t} \cdot \mathrm{ha}^{-1}\right)\end{array}$ \\
\hline ZP 677 & 76,2 & 29,7 & 11,8 & 17,9 & 19,9 \\
\hline ZP 684 & 66,0 & 29,0 & 11,1 & 17,9 & 19,1 \\
\hline ZP 735 & 64,2 & 23,7 & 10,8 & 12,9 & 12,2 \\
\hline ZP 737 & 66,1 & 25,1 & 13,8 & 11,3 & 15,9 \\
\hline
\end{tabular}

Table 9 - Content of dry matter, lignocellulosic fibres and dry matter digestibility of the observed maize hybrids

Таблица 9 - Содержание сухого вещества, лигноцеллюлозных волокон и усвояемость сухого вещества испытуемых гибридов кукурузы *

Табела 9 - Садржај суве материје и лигноцелулозних влакана и сварљивост суве материје проучаваних хибрида кукуруза

\begin{tabular}{|l|l|l|l|l|l|l|l|}
\hline \multirow{2}{*}{ Hybrid } & \multirow{2}{*}{$\begin{array}{l}\text { Whole plant } \\
\text { dry matter } \\
\text { content (\%) }\end{array}$} & \multicolumn{4}{|l|}{ Content of lignocellulosic fibres (\%) } & \multirow{2}{*}{$\begin{array}{l}\text { Dry matter } \\
\text { digestibility } \\
(\%)\end{array}$} \\
\cline { 3 - 8 } & NDF $^{*}$ & ADF* $^{*}$ & ADL* $^{*}$ & $\begin{array}{l}\text { Hemice } \\
\text { llulose* }\end{array}$ & $\begin{array}{l}\text { Cellulos } \\
\mathrm{e}^{*}\end{array}$ & \\
\hline ZP 677 & 38.96 & 41.09 & 19.51 & 1.68 & 21.58 & 17.83 & 68.29 \\
\hline ZP 684 & 44.02 & 39.46 & 18.40 & 1.50 & 21.06 & 16.90 & 65.85 \\
\hline ZP 735 & 35.58 & 60.10 & 32.07 & 3.06 & 28.03 & 29.01 & 51.30 \\
\hline ZP 737 & 38.00 & 42.90 & 22.01 & 3.54 & 18.58 & 18.58 & 63.51 \\
\hline
\end{tabular}

*Source of data, abbreviations and explanations: The analyses of contents of NDF, ADF and ADL were performed according to the method of Van Soest P. J. (Van Soest, 1963); dry matter content was established according to the Rulebook on Sampling Methods and Methods of Physical, Chemical and Microbiological Analyses of Animal Feed (Službeni list SFRJ, 15/87) and dry matter digestibility was obtained by the INRA method, whereas the content of hemicellulose and cellulose was computed (Hemicellulose $=$ NDF - ADF, and Cellulose = ADF - ADL). NDF - neutral detergent fibres; ADF - acid detergent fibres; $A D L$ - acid detergent lignin ( $72 \%$ sulphuric acid) 


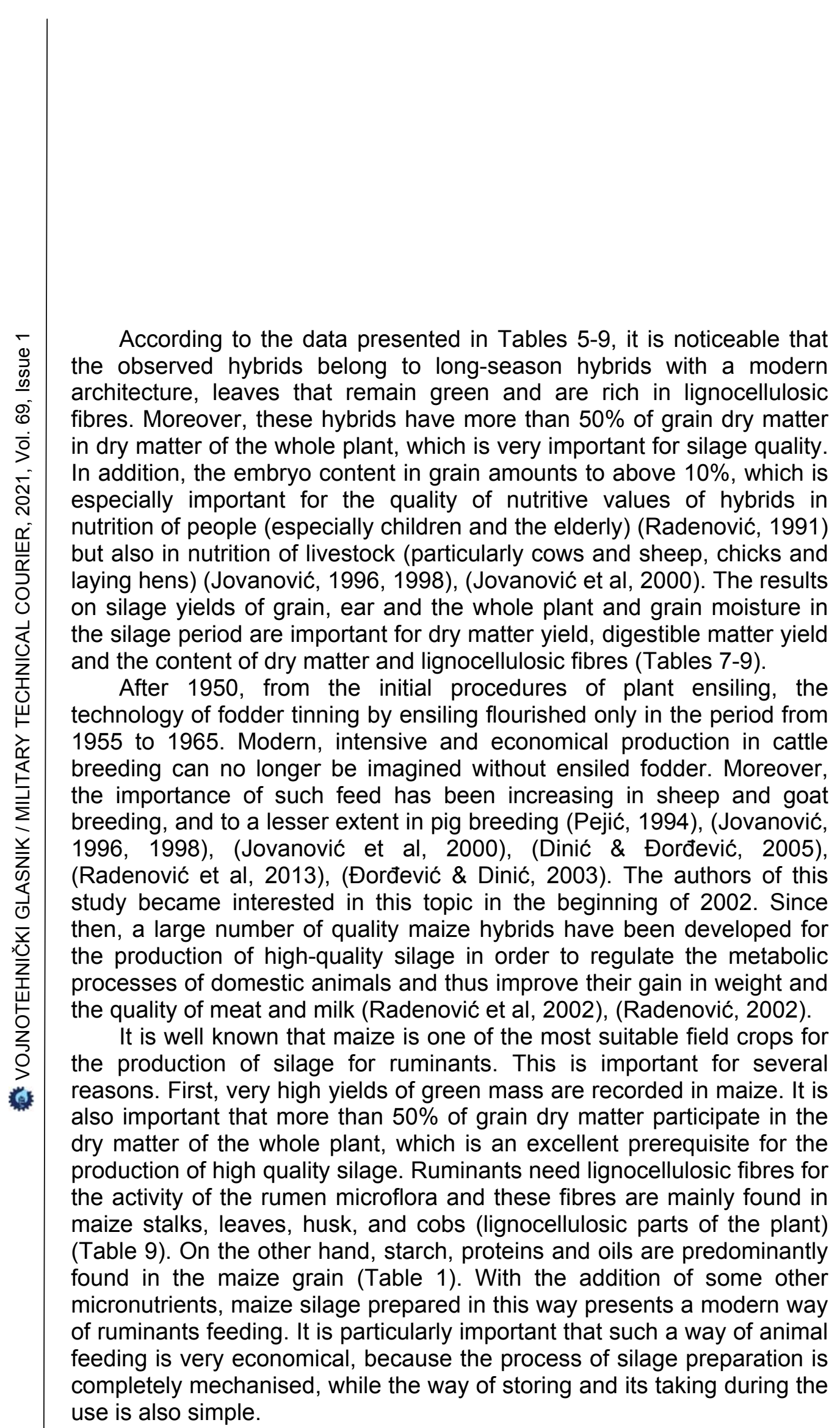


According to the previous studies (Jovanović, 1996, 1998), (Jovanović et al, 2000), the observed hybrids (ZP 677, ZP 684, ZP 735 and ZP 737) have significantly better digestibility than some short-season hybrids, and therefore they belong to the group of the highest quality silage hybrids. It is this fact that indicates the higher nutritional value of these hybrids, which directly affects the productive performances of ruminants. Based on our studies (Radenović, 2002, 2013), the hybrids ZP 677, ZP 684, ZP 735, and ZP 737 had satisfactory yields of green mass silage under the conditions of Leskovac with the application of standard cropping practices and without irrigation. According to the obtained results, the highest yield of green mass was recorded in the maize hybrid ZP 677. However, to draw the final conclusion on which hybrid is more suitable for silage, grain yield as well as silage digestibility should be taken into account. Since these are long-season hybrids (FAO maturity group 750-850), they have a very developed leaf mass and the intensive photosynthetic activity. This, among other things, classifies them into a group of hybrids most suitable for the silage production under the climate conditions of Serbia and Southeastern Europe (Greece, Bulgaria, and Turkey).

As already mentioned, a huge success has been achieved in maize breeding and the production of high quality foundation seed and hybrid seed in the last 42 years. Furthermore, a great success was achieved in modern technologies for the commercial maize production. Since 1978, the number of maize plants per area unit has been significantly increased by the application of the new maize breeding programme. This programme, known as a "plant density" breeding programme, directly affected the increase of yield of both foundation and hybrid seeds as well as the yield of commercial maize (Radenović et al, 2004, 1978). A few years later, the breeding programme for the development of maize inbred lines with erect top leaves - inbreds with more efficient photosynthesis was implemented (Radenović et al 2004, 2008, 2009, 2007). Some of these inbred lines with the erect top leaves were thought to be the closest to the assumed photosynthetic maize model. At the same time, the breeding programme for maize inbreds rich in pigments and other chemical properties and excellent nutritional values was initiated (Kojić \& Ivanović, 1986), (Petrović et al, 1992), (Pejić, 1994), (Jovanović, 1996, 1998), (Dumanović \& Pajić, 1998), (Jovanović et al, 2000), (Dinić \& Đorđević, 2005), (Pajić et al, 1995), (Liu, 2007), (Strati et al, 2012, (Tyutyaev et al, 2015), (Đorđević \& Dinić, 2003), (Kurlich \& Juvik, 1999), (Granado et al, 2003), (Luo \& Wang, 2012). 
This study was an attempt to answer the following question by using different interdependent tests and analyses: „Is there a reliable and dominant trait (one or more) of the observed maize inbred lines rich in the pigment complex that would be the basis for the development of new extra-quality maize hybrids that would be suitable for human diet and nutrition of domestic animals?" The analysis of the presented overall results, obtained in the series of experiments, can easily give the positive answer to this question. Consequently, the new maize inbred lines (ZPPL 146 and ZPPL 159) and the hybrids developed from them (ZP 633, ZP 735 and ZP 737) are the best confirmation of the stated. The bred inbred lines and hybrids developed from them are rich in pigments, have significant nutritive values, especially of carotenoids that give the colour (Abdel-Aal et al, 2006) to cereal kernels used in the nutrition of poultry. Carotenoids have many biological functions in both people and animals (Strati et al, 2012), (Kurlich \& Juvik, 1999), (Granado et al, 2003), (Bacchetti et al, 2013). This aspect of the observed maize inbred lines and hybrids will get priority within the healthy extra-quality maize-based diet for people and nutrition for animals.

\section{Conclusions}

Based on the presented numerous and diverse results of the studies of the new inbred lines (ZPPL 146 and ZPPL 159) and the maize hybrids developed from these inbreds (ZP 633, ZP 735 and ZP 737) that have high nutritive values, are rich in pigments and, in accordance with their chemical composition, have efficient photosynthesis and other relevant parameters characteristic for the best standard maize hybrids (ZP 677 and ZP 684) for silage of grain, ear and the whole plant, the following can be concluded:

- Selected new, unique maize inbred lines (ZPPL 146 and ZPPL $159)$, rich in carotenoids, yellow pigments, also have significant amounts of other relevant bioactive compounds and good physical traits.

- Observed inbred lines have erect top leaves and are classified into a group of maize inbreds with significant properties of the photosynthetic model - they are high yielding and tolerant to high temperatures and drought.

- Spectral bands pointing to the conformational characteristics of molecules of carotenoids but also other compounds (phosphates, glutens, and amides III) were established by the resonance 
Raman spectroscopy method applied to the leaf of the maize inbred lines.

- Relevant traits, properties and parameters of the observed new maize inbred lines that can be successfully used in the breeding process are presented.

- These maize inbred lines were used to develop high yielding and extra quality maize hybrids (ZP 633, ZP 735 and ZP 737) that are recognisable for their quality. The hybrid ZP 633 is particularly recognisable in human nutrition (children and the elderly). Furthermore, in relation to veterinary and agronomic estimations, the hybrids ZP 735 and ZP 737 are the most suitable for feeding domestic animals with a programmed use of maize silage, ground maize and coarse meal.

- Relevant agronomic, morphological and nutritive properties of the maize hybrids ZP 677, ZP 684, ZP 735 and ZP 737 are presented. Moreover, the results regarding the grain structure and grain and silage yields obtained in the regions of Serbia and Southeastern Europe (Greece, Bulgaria, and Turkey) are also displayed.

- All studied maize hybrids (ZP 633, ZP 735, ZP 737, ZP 677, and ZP 684) are intended for large-scale production of flour, semolina, ground maize, silage of grain, ear and the whole plant, which provides healthy and extra quality food and feed.

\section{Special acknowledgement}

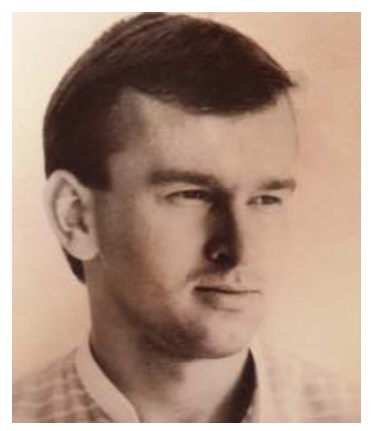

The authors express deep gratitude and appreciation to Dr. Obrad Stojnić (1960 -1997) for his remarkable contribution to the development of Serbian maize breeding and selection. Had his life not been prematurely and forcibly interrupted, his scientific results in maize 
breeding would have been even more successful. Even so, he will be always remembered for his deeds - the Serbian maize breeding has a leading place in Europe.

\section{References}

-AACC International. 2013. AACC International Official Method 14-50.01. In: Approved Methods of the American Association of Cereal Chemists, tenth ed. St. Paul, Minnesota, USA: American Association of Cereal Chemists.

Abdel-Aal, E-S.M., Christoper Young, J. \& Rabbalski, I. 2006. Anthocyanin Composition in Black, Blue, Pink, Purple, and Red Cereal Grains. Journal of Agricultural and Food Chemistry, 54(13), pp.4696-4704. Available at: https://doi.org/10.1021/jf0606609.

Antov, G., Čobić, T. \& Antov, A. 2004. Siliranje i silaže. Novi Sad: Graph Style.

Bacchetti, T., Masciangelo, S., Micheletti, A. \& Ferretti, G. 2013. Carotenoids, Phenolic Compounds and Antioxidant Capacity of Five Local Italian Corn (Zea Mays L.) Kernels. Journal of Nutrition \& Food Sciences, 3(6), pp.1-4. Available at: https://doi.org/10.4172/2155-9600.1000237.

Bekrić, V. 1997. Upotreba kukuruza, pp.201-204. Belgrade: Maize Research Institute "Zemun Polje" (in Serbian).

Bekrić. V. 1999. Industrijska proizvodnja stočne hrane. Belgrade: Maize Research Institute "Zemun Polje" (in Serbian).

Dinić, B. \& Đorđević, N. 2005. Pripremanje i korišćenje silaže. Belgrade: Institut za istraživanje u poljoprivredi "Srbija" (in Serbian).

Dumanović, J. 1986. Savremeni programi oplemenjivanja kukuruza. In: Proceedings of Genetika $i$ oplemenjivanje kukuruza - dostignuća $i$ nove mogućnosti (in Serbian), Belgrade, pp.77-94, December 11-12.

Dumanović, J. \& Pajić, Z. 1998. Specifični tipovi kukuruza. Belgrade: Maize Research Institute "Zemun Polje" (in Serbian).

Duvick, D.N. 1984. Genetic Contribution to Yield Gains of U.S. Hybrid Maize, 1930 to 1980. In: Fehr, W.R. (Ed.) Genetic Contributions to Yield Gains of Five Major Crop Plants, Volume 7, Chapter 2, pp.15-47. Madison, WI, USA, Crop Science Society of America, American Society of Agronomy: CSSA Special Publications. Available at: https://doi.org/10.2135/cssaspecpub7.c2. Serbian).

Đorđević, N. \& Dinić, B. 2003. Siliranje leguminoza. Belgrade: Vizartis (in

Granado, F., Olmedilla, B. \& Blanco, I. 2003. Nutritional and clinical relevance of lutein in human health. British journal of Nutrition, 90(3), pp.487502. Available at: https://doi.org/10.1079/BJN2003927.

Hallauer, A.R. 1988. Modern methods in maize breeding. In: Proceedings of Euromaize '88 - Maize Breeding and Maize Production, Belgrade, October 68. 
Ivanović, M., Petrović, R., Drinić, G., Trifunović, V., Kojić, L., Vuković, M., Mišović, M., Radović, G., Ristanović, D., Pajić, Z. \& Trifunović, B.V. 1995. Pedeset godina selekcije ZP hibrida kukuruza. In: Proceedings of Simpozijum sa međunarodnim učešćem "Oplemenjivanje, proizvodnja i iskorišćavanje kukuruza - 50 godina Instituta za kukuruz "Zemun Polje" (in Serbian), Belgrade, pp.3-16, September 28-29.

Jovanović, R. 1996. Ishrana ovaca. Novi Sad: S Print (in Serbian).

Jovanović, R. 1998. Ishrana krava. Novi Sad: Stylos (in Serbian).

Jovanović, R., Dujić, D. \& Glamočić, D. 2000. Ishrana domaćih životinja. Novi Sad: Stylos (in Serbian).

Karnauhov, V.N. 1988. Biologicheskie funkcii karotenoidov. Moscow: Nauka (in Russian). (In the original: Карнаухов, В.Н. 1988. Биологические фуннкции каротиноидов. Москва: Наука.)

Kojić, L. \& Ivanović, M. 1986. Dugoročni programi oplemenjivanja kukuruza. In: Proceedings of Genetika i oplemenjivanje kukuruza - dostignuća i nove mogućnosti (in Serbian), Belgrade, pp.57-75, December 11-12.

Konstantinov, K., Mladenović-Drinić, S., Anđelković, V. \& Babić, M. 2010. Ethics in scientific results application: gene and life formspatenting. Genetika, 42(1), pp.195-208. Available at: https://doi.org/10.2298/GENSR1001193K.

Kurlich, A.C. \& Juvik, J.A. 1999. Quantification of Carotenoid and Tocopherol Antioxidants in Zea mays. Journal of Agricultural and Food Chemistry, 47(5), pp.1948-1955. Available at: https://doi.org/10.1021/jf981029d.

Liu, R.H. 2007. Whole grain phytochemicals and health. Journal of Cereal Science, 46(3), pp.207-219. Available at: https://doi.org/10.1016/j.jcs.2007.06.010.

Luo, Y. \& Wang, Q. 2012. Bioactive compounds in corn. In: Yu, L., Tsao, R. \& Shahidi, F. (Eds) Cereals and Pulses: Nutraceutical Properties and Health Benefits, pp.85-103. Hoboken, New Jersey: John Wiley \& Sons, Inc.

Pajić, Z., Mišović, M., Dumanović, J., Mišević, D., Babić, M. \& Saratlić, G. 1995. Selekcija kukuruza specifičnih svojstava i namene. In: Proceedings of Simpozijum sa međunarodnim učešćem "Oplemenjivanje, proizvodnja i iskorišćavanje kukuruza - 50 godina Instituta za kukuruz "Zemun Polje" (in Serbian), Belgrade, pp.229-237, September 28-29.

Pejić, Đ. 1994. Silažni kukuruz - tehnologija proizvodnje i siliranja. Belgrade: Maize Research Institute "Zemun Polje" (in Serbian).

Petrović, R., Filipović, M. \& Vidaković M. 1992. Identifikacija izvora koji sadrže poželjne alele za poboljšanje roditeljskih komponenata elitnih hibrida kukuruza (Zea Mays L.). Genetika, 24(2), pp.115-126 [online]. Available at: http://www.dgsgenetika.org.rs/abstrakti/vol24_1992_no2_sr.htm\#Rad7 (in Serbian) [Accessed: 15 November 2020].

Radenović, Č. 1991. Programirana ishrana dece sa kukuruzom doprinosi regulisanju metabolizma njihovog efikasnog rastenja i razvića. Belgrade: Society of Biophysicists of Serbia (in Serbian). 
Radenović, Č. 1994. Review, a study of delayed fluorescence in plant models: photosynthetic, transportation and membrane processes. Journal of the Serbian Chemical Society, 59(9), pp.595-617.

Radenović, Č. 2002. Programirana ishrana domaćih životinja (goveda i ovce) silažom od kukuruza - doprinos regulisanju metabolizma njihovog prirasta $i$ kvalitetu mesa i mleka. Belgrade: Society of Biophysicists of Serbia (in Serbian).

Radenović, Č.N. 2013. Deset godina proizvodnje hibrida kukuruza za zrno $i$ silažu u agroekološkim uslovima: Puste Reke, Toplice i Dubočice. Programirana kampanja za ishranu ljudi sa proizvodima od kukuruza i domaćih životinja sa kukuruznom silažom. Belgrade: Society of Biophysicists of Serbia (in Serbian).

Radenović, Č., Babić, M., Delić, N., Šatarić, I. \& Kojić, L. 2002. Novyj fotosintetichesko-bioljuminescentnyj metod $\mathrm{v}$ selekcii kukuruzy. Kukuruza $i$ sorgo, 4, pp.21-24, in Russian. (In the original: Раденович, Ч., Бабич, М., Делич, Н., Шатарич, И. и Коич, Л. 2002. Новый фротосинтетическобиолюминесцентный метод в селекции кукурузы. Кукуруза и сорго, 4, стр.21-24.)

Radenović, Č., Babić, M., Hojka, Z., Stanković, G., Trifunović, B.V., Ristanović, D., Delić, N. \& Selaković, D. 2004. Properties of maize inbred lines with erect leaves as efficient photomodels in breeding. Doklady Rossijskoj akademii sel'skohozjajstvennyh паик/Доклады Российской академии сельскохозяйственных наук, 2, pp.7-9 [online]. Available at: https://www.elibrary.ru/item.asp?id=18281407 (in Russian) [Accessed: 15 November 2020].

Radenović, Č., Filipović, M., Anđelković, V., Babić, M. \& Radojčić, A. 2009. Significant breeding properties of inbred maize lines as the basis for creating new, higher yielding hybrids. Russian Agricultural Sciences, 35(6), pp.374-377. Available at: https://doi.org/10.3103/S1068367409060044.

Radenović, Č., Filipović, M. \& Babić, M. 2013. Međuzavisnost procesa zakasnele fluorescencije hlorofila, fotosinteze i oplemenjivanja kukuruza. Novi Sad: Matica srpska \& Belgrade: Maize Research Institute "Zemun Polje" (in Serbian).

Radenović, Č., Filipović, M., Babić, M., Stanković, G., Radojčić, A., Sečanski, M., Pavlov, J., Radojčić Branković, D. \& Selaković, D. 2008. Actual prestigious properties of maize inbred lines - a good initial basis for the efficient development of new and yielding maize hybrids. Genetika, 40(2), pp.121-133. Available at: https://doi.org/10.2298/GENSR0802121R.

Radenović, Č., Grodzinskij, D.M., Filipović, M., Radosavljević, M., Videnović, Ž., Denić M. \& Čamdžija, Z. 2010. The Prestigious Maize Inbred Lines and Hybrids with Erect Top Leaves are Characterised by a Property of an Efficient Photosynthetic Model and a Satisfactory Base for the Further Progress in Breeding and Selection. Plant Physiology and Genetics, 42(3), pp.187-201.

Radenović, Č., Jeremić, M., Maximov, G.V., Filipovović, M., Trifunović, B.V., Mišović, M.M. 1994. Mogućnost korišćenja ramanske spektroskopije u proučavanju otpornosti inbred linija kukuruza prema uslovima stresa. Savremena poljoprivreda/Contemporary Agriculture, 42(1-2), pp.5-19 (in Serbian). 
Radenović, Č., Jeremić, M., Maximov, G.V., Mišović, M.M. \& Selaković, D. 1998. Ressonance raman spectra of carotenodes in the maize kernel - a contribution to the evaluation of the kernels resistence to the temperature and the chemical composition of soil. Matica srpska journal for natural sciences, 95, pp.41-50.

Radenović, Č., Jeremić, M., Maximov, G.V., Mišović, M.M., Selaković, D. \& Trifunović B.V. 1995. Rezonantni ramanski spektri semena kukuruza i njihova primena u proučavanju životnih funkcija. In: Proceedings of Simpozijum sa međunarodnim učešćem "Oplemenjivanje, proizvodnja i iskorišćavanje kukuruza - 50 godina Instituta za kukuruz "Zemun Polje" (in Serbian), Belgrade, pp.291296, September 28-29.

Radenović, Č., Konstantinov, K., Delić, N. \& Stanković, G. 2007. Photosynthetic and bioluminiscence properties of maize inbred lines with upright leaves. Maydica, 52(3), pp.347-356.

Radenović, Č., Ristanović, D. \& Trifunović, V. 1978. The theoretical and the development programme on the increase of the plant number per area unit for the development of erect leaf maize lines and for their more effective application in breeding. Belgrade: Maize Research Institute "Zemun Polje".

Radenović, Č. \& Somborac M. 2000. Kukuruz na pragu trećeg milenijuma sećanja, kazivanja i predviđanja. Belgrade: Maize Research Institute "Zemun Polje" (in Serbian).

Radenović, Č., Šatarić, I., Husić, I., Mišović, M.M., Filipović, M. \& Kojić, L. 2000. A study of functioning of thylakoid membranes in inbred lines of maize (Zea mays L.). Genetika, 32(3), pp.377-386 [online]. Available at: http://www.dgsgenetika.org.rs/abstrakti/vol32_2000_no3_en.htm\#Rad13

[Accessed: 15 November 2020].

Radosavljević, M., Bekrić, V., Božović, I. \& Jakovljević, J. 2000. Physical and chemical properties of various corn genotyps as a criterion of technological qality. Genetika, 32(3), pp.319-329 [online]. Available at: http://www.dgsgenetika.org.rs/abstrakti/vol32_2000_no3_en.htm\#Rad9 [Accessed: 15 November 2020].

-Službeni list SFRJ. 15/87. Pravilnik o metodama uzimanja uzoraka $i$ metodama fizičkih, hemijskih i mikrobioloških analiza stočne hrane. Belgrade: Novinsko-izdavačka ustanova Službeni list SFRJ (in Serbian).

Sprague, G.F. 1984. Organization of breeding programs. 20th Ann. Illinois Corn Breeding School (USA), 20, p.20.

Strati, I.F., Sinanoglou, V.J., Kora, L., Miniadis-Meimaroglou, S. \& Oreopoulou, V. 2012. Carotenoids from Foods of Plant, Animal and Marine Origin: An Efficient HPLC-DAD Separation Method. Foods, 1(1), pp.52-65. Available at: https://doi.org/10.3390/foods1010052.

Trifunović, V. 1986. Četrdeset godina moderne selekcije kukuruza u Jugoslaviji. In: Proceedings of Genetika i oplemenjivanje kukuruza - dostignuća i nove mogućnosti (in Serbian), Belgrade, pp.5-46, December 11-12. 
Tyutyaev, E.V., Shutova, V.V., Maksimov, G.V., Radenovic, C.N. \& Grodzinskij, D.M. 2015. State of photosynthetical pigments in leaves of inbred lines and hybrids of maize. Fiziologija rastenij i genetika/Физиология растений u генетика, 47(2), pp.147-159 [online]. Available at: https://core.ac.uk/download/pdf/232903699.pdf (in Russian) [Accessed: 15 November 2020].

Van Soest, P.J. 1963. Use of Detergents in the Analysis of Fibrous Feeds. II. A Rapid Method for the Determination of Fiber and Lignin. Journal of the Association of Official Agricultural Chemists, 46, pp.829-835 [online]. Available at: https://catalogo.latu.org.uy/opac_css/doc_num.php?explnum_id=1479 [Accessed: 15 November 2020].

Videnović, Ž., Simić, M., Srdić, J. \& Dumanović, Z. 2011. Long term effects of different soil tillage systems on maize (Zea mays L.) yields. Plant, Soil and Environment, 57(4), pp.186-192. Available at: https://doi.org/10.17221/443/2010PSE.

White, P.J. \& Johnson, L.A. 2003. Corn: Chemistri aned Technology, pp.71-101. Eagan, Minnesota, USA: American Association of Cereal Chemists. ISBN-13: 978-1891127335. ISBN-10: 1891127330.

\section{ВЫСОКОУРОЖАЙНЫЕ И ХИМИЧЕСКИ ОБОГАЩЕННЫЕ ГИБРИДЫ КУКУРУЗЫ СЕРБСКОЙ СЕЛЕКЦИИ - ЛУЧШАЯ ОСНОВА ДЛЯ ВЫСОКОКАЧЕСТВЕННЫХ ПРОДУКТОВ ПИТАНИЯ И КОРМОВ ДЛЯ ДОМАШНИХ ЖИВОТНЫХ}

Чедомир. Н. Раденович ${ }^{\mathrm{a}, 6}$, Ненад. С. Делич ${ }^{\mathrm{a}}$, Милица М. Радосавлевич ${ }^{\mathrm{a}}$, Живота В. Йованович ${ }^{a}$, Миле Д. Сечански ${ }^{a}$, Александар С. Поповича Милош С. Цревар ${ }^{a}$, Небойша Д. Радосавлевич ${ }^{a}$

а Институт кукурузы „Земун Поле“, г. Белград, Республика Сербия

${ }^{\sigma}$ Белградский университет, факультет физической химии,

г. Белград, Республика Сербия, корреспондент

РУБРИКА ГРНТИ: 31.27.00 Биологическая химия; 31.27.29 Биохимия питания и кормления. 31.15.00 Физическая химия

ВИД СТАТЬИ: оригинальная научная статья

Резюме:

Введение/цель: В данной статье представлены результаты ряда различных исследований. Селекция инбредных линий ZPPL 146 и ZPPL 159, произведенная на основе гибридов кукурузы, предназначенных в первую очередь для производства продуктов питания и кормов для домашних животных, заняла около четырех десятилетий: ZP 633, ZP 735 и ZP 737.

Методы: В исследовании применялся метод резонансной рамановской спектроскопии листьев инбредных линий кукурузы, с 
помощью которой были обнаружены спектральные полосы, которые указывают на конформационные характеристики молекул каротиноидов, а также других соединений (фоосфата, глютена и амида III).

Результаты: На основании проведенного систематического исследования инбредных линий: ZPPL 146 и ZPPL 159 и гибридов кукурузы: ZP 633, ZP 735 и ZP 737 выявлено, что новые инбредные линии кукурузы: ZPPL 146 и ZPPL 159 богаты каротиноидами и желтыми пигментами. Эти линии в большом объеме обладают и другими важными биологически активными соединениями и благоприятными фризическими характеристиками. Изучаемые инбредные линии кукурузы отличаются прямостоячим положением верхних листьев и относятся $к$ группе линий кукурузы со значительными характеристиками модели фотосинтеза. Это жаростойкие и засухоустойчивые растения.

Выводы: B данной статье представлены релевантные свойства, характеристики и параметры изученных новых инбредных линий кукурузы, которые в перспективе могут быть использованы в процессе селекции. С помощью вышеуказанных инбредных линиий кукурузы созданы высокоурожайные и высококачественные гибриды кукурузы: ZP 633, ZP 735 и ZP 737, отличающиеся по своим качествам. Особенно узнаваем гибрид ZP 633, предназначенный для производства продуктов питания (для детей и пожилых людей).

Ключевые слова: замедленная фрлуоресценция хлорофрилла, рамановская спектроскопия, модель фотосинтеза, Zea mays $L$, инбредная линия, гибрид, тилакоидная мембрана, пигментные свойства, пищевая ценность, продукты питания и корма для домашних животных.

ВИСКОПРИНОСНИ И ХЕМИЈСКИ ОБОГАЋЕНИ ХИБРИДИ КУКУРУЗА СРПСКЕ СЕЛЕКЦИЈЕ КАО НАЈБОЉА ОСНОВА ЗА НАЈКВАЛИТЕТНИЈУ ХРАНУ

Чедомир. Н. Раденовић, ${ }^{\mathrm{a},}$, Ненад. С. Делић ${ }^{\mathrm{a}}$ Милица М. Радосављевић ${ }^{\mathrm{a}}$, Живота В. Јовановић ${ }^{\mathrm{a}}$, Миле Д. Сечански ${ }^{\mathrm{a}}$, Александар С. Поповић ${ }^{\mathrm{a}}$, Милош С. Цревар ${ }^{a}$, Небојша Д. Радосављевић ${ }^{a}$

а Институт за кукуруз „Земун Поље“, Београд, Република Србија

${ }^{5}$ Универзитет у Београду, Факултет за физичку хемију,

Београд, Република Србија, аутор за преписку

ОБЛАСТ: фризичка хемија, биофизика, генетика, биохемија и технологије за прераду биљних сировина

ВРСТА ЧЛАНКА: оригинални научни рад 


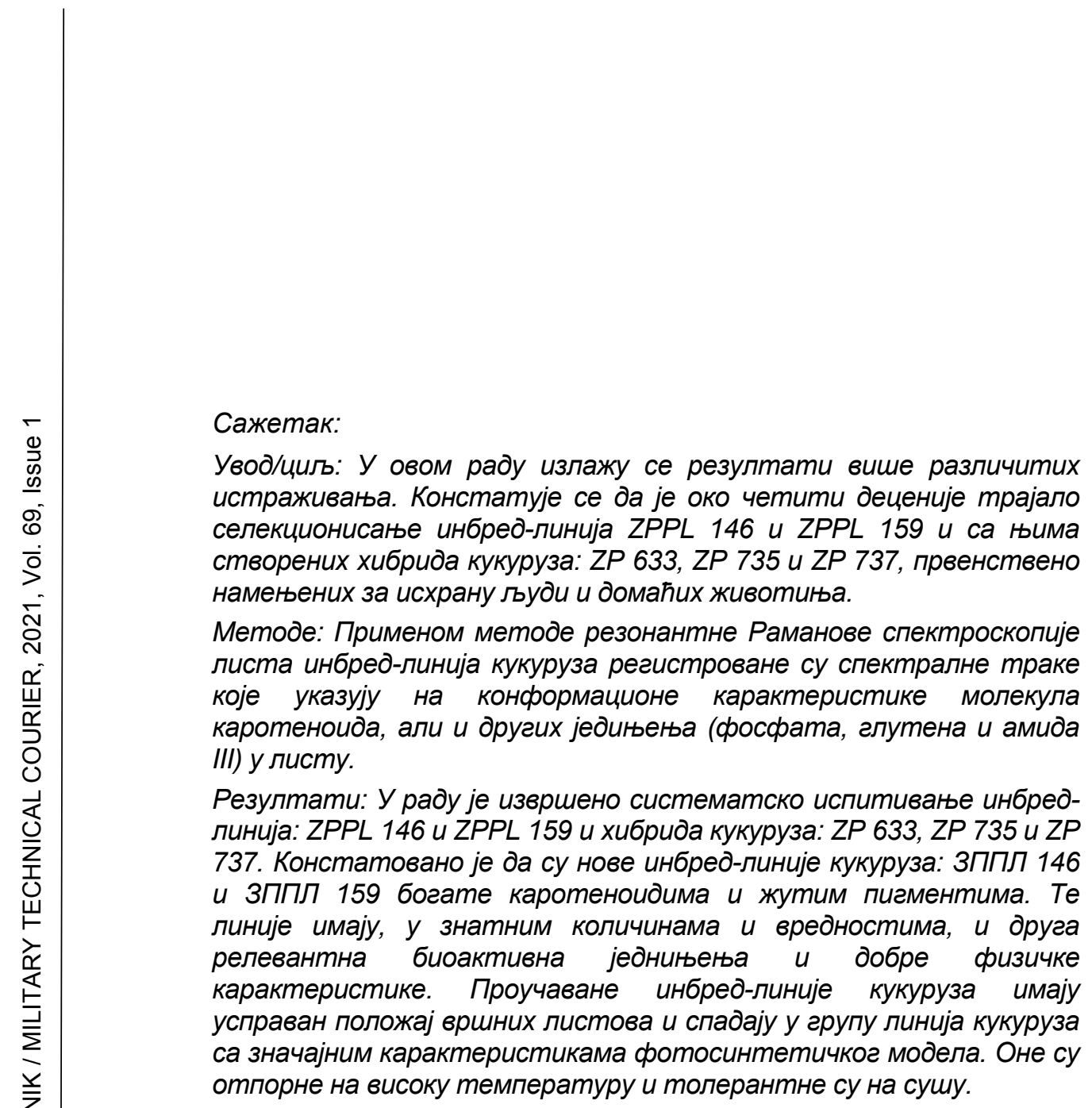

Закључак: У раду су изложена релевантна својства, карактеристике и параметри проучаваних нових инбред-линија кукуруза која се могу користити у будућности у селекционом процесу. Са наведеним инбред-линијама кукуруза створени су високоприносни и квалитетни хибриди кукуруза: ZP 633, ZP 735 и ZP 737, који су препознатљиви по својим квалитетима, а нарочито хибрид ZР 633 за исхрану људи (деце и старијих лица). Исто тако, са агрономско-ветеринарског становишта је потврђено да су хибриди ZP 735 и ZP 737 најпогоднији за исхрану домаћих животиња уз програмирано коришћење кукурузне силаже. Такође, изложена су релевантна агрономска, морфолошка и нутритивна својства хибрида кукуруза ZP 633, ZP 735 и ZP 737. Презентовани су и резултати о структури зрна и висини приноса за зрно и силажу и код хибрида ZP 677 и ZP 684, који се производе у Србији и земљама југоисточне Европе.

Кључне речи: закаснела фрлуоресценција хлорофила, Раманова спектроскопија листа, фотосинтетички модел, Zea mays $L$, инбред-линија, хибрид, тилакоидна мембрана, пигментна својства, нутритивна вредност, храна за људе и животиње. 
Paper received on / Дата получения работы / Датум пријема чланка: 21.11.2020. Manuscript corrections submitted on / Дата получения исправленной версии работы / Датум достављања исправки рукописа: 25.12.2020.

Paper accepted for publishing on / Дата окончательного согласования работы / Датум коначног прихватања чланка за објављивање: 27.12.2020.

(c) 2021 The Authors. Published by Vojnotehnički glasnik / Military Technical Courier

(www.vtg.mod.gov.rs, втг.мо.упр.срб). This article is an open access article distributed under the terms and conditions of the Creative Commons Attribution license (http://creativecommons.org/licenses/by/3.0/rs/).

(c) 2021 Авторы. Опубликовано в «Военно-технический вестник / Vojnotehnički glasnik / Military Technical Courier» (www.vtg.mod.gov.rs, втг.мо.упр.срб). Данная статья в открытом доступе и распространяется в соответствии с лицензией «Creative Commons» (http://creativecommons.org/licenses/by/3.0/rs/).

(c) 2021 Аутори. Објавио Војнотехнички гласник / Vojnotehnički glasnik / Military Technical Courier (www.vtg.mod.gov.rs, втг.мо.упр.срб). Ово је чланак отвореног приступа и дистрибуира се у складу са Creative Commons licencom (http://creativecommons.org/licenses/by/3.0/rs/).

(c) (i) 